This is an Accepted Manuscript of an article published by Taylor \& Francis in the

Oxford University Commonwealth Law Journal, Vol. 13, Issue 1 (2013), pp. 115 -

156, available online: https://doi.org/10.5235/14729342.13.1.115

\title{
THE ACCOUNTABILITY OF MEMBERS OF AUSTRALIA'S FEDERAL PARLIAMENT FOR MISCONDUCT
}

\author{
Alysia BlaCKHAM* AND GEORGE WILLIAMS **
}

\begin{abstract}
Recent times have seen serious allegations of misconduct made against members of Australia's federal Parliament. This has led to calls for more effective parliamentary and independent mechanisms to address allegations of misbehaviour. Drawing on comparative perspectives from the United Kingdom and Republic of Ireland and laws in place in the Australian States and Territories, this article considers the extent to which additional measures would assist the Australian federal Parliament to manage the misconduct of its members. It proposes a model of extended accountability to provide more robust mechanisms for the management of parliamentary misconduct.
\end{abstract}

\section{INTRODUCTION}

Recent times have seen serious allegations of misconduct made against members of Australia's federal Parliament. In May 2012, a Fair Work Australia report was released which found that federal Labor MP Craig Thomson had committed 156 breaches of workplace laws while employed as a union official, including by spending almost $\$ 6,000$ on escort services using

\footnotetext{
* BA/LLB (Hons) (Melb), PhD student, Gonville and Caius College, University of Cambridge; Honorary Fellow, Faculty of Law, University of Western Australia.

${ }^{* *}$ BEc, LLB (Hons), LLM (UNSW), PhD (ANU); Anthony Mason Professor, Scientia Professor and Foundation Director, Gilbert + Tobin Centre of Public Law, Faculty of Law, University of New South Wales; Australian Research Council Laureate Fellow; Barrister, New South Wales Bar.
} 
union credit cards. ${ }^{1}$ At the same time, federal Speaker Peter Slipper was accused of misusing parliamentary Cabcharge vouchers and sexually harassing a male staffer. ${ }^{2}$ These 'unsavoury findings' ${ }^{3}$ and allegations led to a series of 'tawdry political jousts' in the media and in Parliament. ${ }^{4}$ Concerns were raised that the political response to the scandals was inadequate and, as a result, the incidents were 'damaging all politicians'. ${ }^{5}$ It was also suggested that the behaviour of Thomson and Slipper had triggered 'a public loss of faith in [Parliament] and its members ${ }^{6}$ and was 'destroying public confidence in the integrity of Parliament'. ${ }^{7}$

The Thomson and Slipper cases led people to question whether existing processes and procedures for managing parliamentarians' misconduct were adequate. As the cases progressed, statements were repeatedly made in the media and political circles that Australia lacked an effective parliamentary architecture to deal with allegations of misconduct by members of Parliament. ${ }^{8}$ The systems in place were, for example, criticised as being 'totally out-of-date', ${ }^{9}$ leading to calls for more effective parliamentary and independent mechanisms to address allegations of misconduct and 'rebuild public confidence in the parliamentary system'.${ }^{10}$ New mechanisms proposed in the media and by members of Parliament included a parliamentary Code of Conduct, ${ }^{11}$ independent integrity commissioners empowered to

\footnotetext{
${ }^{1}$ Terry Nassios, Report of the Delegate to the General Manager of Fair Work Australia: Investigation into the National Office of the Health Services Union Under Section 331 of the Fair Work (Registered Organisations) Act 2009 (Fair Work Australia 2012). See also 'Fair Work Report Finds Thomson Misused Union Funds' ABC News (Sydney, 7 May 2012) <http://www.abc.net.au/news/2012-05-07/fair-work-report-into-hsu-released/3996274> accessed 22 September 2012; Pip Freebairn, 'Investigator Defends Thomson Probe' The Australian Financial Review (Sydney, 17 July 2012) 4; 'Gillard Flags Code of Conduct Amid Thomson Affair' ABC News (Sydney, 14 May 2012) <http://www.abc.net.au/news/2012-05-13/gillard-flags-mps-code-in-wake-of-thomsonaffair/4008356> accessed 22 September 2012.

${ }^{2}$ Speaker's Office, House of Representatives, 'Statement by the Hon Peter Slipper, MP' (26 April 2012); James Hunter Ashby, 'Originating Application under the Fair Work Act 2009 Alleging Discrimination', Submission in Ashby v Commonwealth, NSD 580/2012, 20 April 2012, 2; Ashby v Commonwealth (No 4) [2012] FCA 1411 (12 December 2012); Australian Federal Police, 'Information and Summons', Filed in $R v$ Peter Neil Slipper, CC 40001-3 of 2013, 3 January 2013.

${ }^{3}$ Editorial, 'Union Members the Real Losers in HSU Scandal' The West Australian (Perth, 25 July 2012) 20.

${ }^{4}$ Editorial, 'Political and Media Games Tarnish Sexual Allegations' The Australian (Sydney, 1 August 2012) 13.

${ }^{5}$ Dennis Shanahan, 'Enough is Enough, Say all Sides of the House, as Debates Hit the Gutter' The Australian (Sydney, 30 May 2012) 4.

6 'Pollies Caught Out by Public Expectations' The Australian (Sydney, 26 May 2012) 15.

${ }^{7}$ Phillip Hudson, 'High Time for an Umpire in Parliament' Herald-Sun (Melbourne, 25 May 2012) 39.

${ }^{8}$ Paul Kelly, 'Thomson Affair Shows the Need for a Federal ICAC' The Australian (Sydney, 23 May 2012) 12.

${ }^{9}$ AJ Brown, 'Affair Casts Light on Failed System' The Australian (Sydney, 25 May 2012) 32.

${ }^{10}$ Steven Scott, 'Code of Conduct for MPs is One Shot in Battle to Lift Political Standards' The Courier-Mail (Brisbane, 24 May 2012) 28.

${ }^{11}$ Geoff Kitney, 'Code Seems More Necessary than Ever' The Australian Financial Review (Sydney, 23 May 2012) 1; Alex Malley, 'Code Won't Keep MPs in Line' The Australian Financial Review (Sydney, 24 May 2012) 71; 'Pollies Caught Out by Public Expectations' (n 6); Scott (n 10); Shanahan (n 5); Lenore Taylor, 'Political Feeding Frenzy a Plague on Both Houses’ The Sydney Morning Herald (Sydney, 26 May 2012) 17.
} 
investigate parliamentary misconduct and enforce a Code of Conduct ${ }^{12}$ and extending the grounds set out in the Australian Constitution for disqualification of members of Parliament to include civil offences and breaching community standards. ${ }^{13}$

While the Thomson and Slipper cases have reactivated public discussion on managing parliamentary misconduct, there has been limited analysis of how any new mechanisms might work in practice. Further, there has been little considered analysis of whether Parliament should have an extended capacity to discipline its members for misconduct, or whether this is more appropriately a matter for the courts and the electorate. ${ }^{14}$ It has also yet to be established whether these controversies actually provide a strong case for reforming the capacity for Parliament to discipline is members.

In this article, we consider the extent to which existing mechanisms adequately respond to issues of parliamentary misconduct and the extent to which any gaps in accountability are evident. Further, we consider whether additional mechanisms would assist the Australian federal Parliament to manage the misconduct of its members. In answering these questions, it is important that we identify the nature of the problem, that is, what we mean by 'misconduct' on the part of parliamentarians. Misconduct can be broadly defined as actions contrary to the 'institutional rules, norms and common understandings that frame appropriate behaviour' ${ }^{15}$ Whether behaviour constitutes misconduct is often a subjective judgment, with standards of impropriety varying from individual to individual. ${ }^{16}$

For the purposes of this article we define misconduct as behaviour that is contrary to the accepted standards of conduct for members of Parliament and which impinges or has the potential to impinge on a member's performance of their parliamentary duties, including by undermining public confidence in Parliament. Our focus is upon parliamentary misconduct that falls short of corruption, while acknowledging the difficulties inherent in drawing a bright

\footnotetext{
12 Brown (n 9); Hudson (n 7); Kitney (n 11).

${ }^{13}$ Greg Barns, 'An Unfair Case of Trial by Media' Hobart Mercury (Hobart, 28 May 2012) 20; Hudson (n 7); Lenore Taylor, 'MPs Prefer to Sling Mud than Clean it Up' The Sydney Morning Herald (Sydney, 23 May 2012) 4.

14 'Gillard Flags Code of Conduct Amid Thomson Affair' ABC News (Sydney, 14 May 2012) $<$ http://www.abc.net.au/news/2012-05-13/gillard-flags-mps-code-in-wake-of-thomson-affair/4008356> accessed 22 September 2012.

${ }^{15}$ Nicholas Allen, 'Dishonourable Members? Exploring Patterns of Misconduct in the Contemporary House of Commons' (2011) 6 British Politics 210, 211.

16 Ibid 213.
} 
dividing line between the two. ${ }^{17}$ The issues raised by corruption in public office are complex, and fall beyond the scope of this article.

We commence this article by analysing existing mechanisms for managing the misconduct of members of Australian Parliament and the extent to which they reveal any gaps in accountability. We then examine comparative perspectives from the United Kingdom, the Republic of Ireland and the Australian States and Territories to ascertain other means by which Parliament could deal with members' misconduct. Finally, we consider whether such mechanisms are appropriate in the Australian Federal context.

\section{EXTERNAL FORMS OF ACCOUNTABILITY}

\section{A Representative Government and 'Ballot Box'Accountability}

In Australia's system of representative and responsible government the electorate is regarded as the final judge and arbiter of misconduct by members of Parliament, with politicians subject to 'ultimate accountability' for their actions by the electorate at the ballot box. ${ }^{18}$ In the event that parliamentary misconduct is unacceptable to the electorate, a member of Parliament may lose their seat at the next election. In this model, accountability is realised through the ballot box.

In practice, electoral accountability is beset by a number of challenges. First, voters are unlikely to have complete information about a candidate's behaviour, jeopardising their ability to make an informed judgement about politicians' conduct. ${ }^{19}$ Second, individual voters are likely to have different standards regarding how they expect politicians to behave, making it difficult to enforce coherent behavioural standards through elections. ${ }^{20}$ Finally, it is possible that voters themselves do not see elections as a means of securing politicians' accountability, instead using

\footnotetext{
${ }^{17}$ See, for example, Robert Harris, Political Corruption: In and Beyond the Nation State (Routledge 2003$) 1$.

18 Australian Capital Television Pty Ltd v Commonwealth (1992) 177 CLR 106, 230 (McHugh J). See also Nationwide News Pty Ltd v Wills (1992) 177 CLR 1, 70 (Deane and Toohey JJ); Theophanous v Herald \& Weekly Times Ltd (1994) 182 CLR 104, 180 (Deane J).

19 James D. Fearon, 'Electoral Accountability and the Control of Politicians: Selecting Good Types versus Sanctioning Poor Performance' in Adam Przeworski, Susan C. Stokes and Bernard Manin (eds), Democracy, Accountability and Representation (Cambridge University Press 1999) 55, 55; Bernard Manin, Adam Przeworski and Susan C. Stokes, 'Elections and Representation' in Adam Przeworski, Susan C. Stokes and Bernard Manin (eds), Democracy, Accountability and Representation (Cambridge University Press 1999) 29, 42.

${ }^{20}$ Fearon (n 19) 55; Manin, Przeworski and Stokes (n 19) 43-44.
} 
elections as a way of choosing better candidates based on their election promises. ${ }^{21}$ This is further complicated by the presence of political parties, as individual voting preferences may reflect decisions around the performance of the government and the opposition, rather than individual members. ${ }^{22}$ It is clear that the ballot box offers an incomplete and sometimes ineffective means of holding members accountable for misconduct. ${ }^{23}$

\section{B Accountability to the Courts}

Like other citizens, members of Parliament are accountable to the courts for their behaviour, being liable to both civil and criminal penalties for misconduct. For example, Peter Slipper has been charged with dishonestly causing a risk of loss to the Commonwealth under s 135.1(5) of the Criminal Code Act 1995 (Cth) following alleged misuse of parliamentary Cabcharge vouchers $^{24}$ and was (unsuccessfully) pursued in the civil courts for sexual harassment. ${ }^{25}$ Similarly, Craig Thomson has been charged with various fraud offences ${ }^{26}$ and is being pursued in the civil courts by Fair Work Australia. ${ }^{27}$ The courts offer important advantages in resolving misconduct by members of Parliament, being independent from Parliament and having considerable experience in adjudicating matters impartially according to law. Judicial accountability is assisted by the existing protocol for managing allegations of misuse of parliamentary entitlements: under the protocol, the Department of Finance and Deregulation is responsible for investigating allegations of entitlement misuse by members, including by the establishment of a high level Departmental Committee for the investigation of serious cases. Serious matters are referred to the Australian Federal Police following the Department's investigation in order to determine whether proceedings should be brought in court. ${ }^{28}$

\footnotetext{
${ }^{21}$ Manin, Przeworski and Stokes (n 19) 44.

22 A H Birch, Representative and Responsible Government: An Essay on the British Constitution (George Allen \& Unwin 1964) 236. See also Nick Vivyan, Markus Wagner and Jessica Tarlov, 'Representative Misconduct, Voter Perceptions and Accountability: Evidence from the 2009 House of Commons Expenses Scandal' (2012) 31 Electoral Studies 750.

${ }^{23}$ Fearon (n 19) 68; Manin, Przeworski and Stokes (n 19) 49.

${ }^{24}$ Australian Federal Police, 'Information and Summons', Filed in $R$ v Slipper, CC 40001-3 of 2013, 3 January 2013.

${ }^{25}$ Ashby v Commonwealth (No 4) [2012] FCA 1411 (12 December 2012).

${ }^{26}$ Simon Cullen, 'Police Arrest MP Craig Thomson on 150 Fraud Charges' ABC News (Sydney, 1 February 2013) $<$ http://www.abc.net.au/news/2013-01-31/craig-thomson-arrested/4493722> accessed 5 February 2013.

${ }^{27}$ Fair Work Australia v Thomson, VID 798 of 2012.

${ }^{28}$ Department of Finance and Deregulation, Protocol Followed when an Allegation is Received of Alleged Misuse of Entitlement by a Member or Senator $(17 \quad$ July $\quad 2012)$ $<$ http://maps.finance.gov.au/Protocol_on_Allegations.htm> accessed 22 September 2012.
} 
Courts only have the capacity to hear cases of misconduct that breach the law. Some forms of misconduct, such as serious ethical breaches, may not fall into this category. Court processes can also be very slow - in many cases of misconduct, members have left Parliament as their term has lapsed before any criminal case against them is complete. For example, in 2000 Andrew Theophanous MP of the Australian Labor Party was alleged to have sought or obtained money and sexual favours to help Chinese nationals with visa applications and immigration matters. ${ }^{29}$ Theophanous was ultimately convicted of bribery, fraud and conspiracy in 2002 and sentenced to 21 months imprisonment. ${ }^{30}$ Prior to the court's decision, Theophanous failed to retain his parliamentary seat at the 2001 general election after he ran as an independent following his failure to retain pre-selection as a Labor candidate. While this may arguably reflect successful 'ballot box' accountability, it is more likely a reflection of the voting patterns of the Australian electorate, which tend to favour candidates with a party affiliation over independents. ${ }^{31}$

In other cases, members of Parliament have resigned or retired long before any criminal case against them is finalised. In 1997, Mal Colston was alleged to have defrauded the Commonwealth by misusing parliamentary travel allowances. ${ }^{32}$ Colston was charged in 1997 but not prosecuted due to ill health and retired from the Senate at the end of his term on 30 June 1999. ${ }^{33}$ In 1999, Bob Woods claimed an allowance for nights spent at the apartment of a staffer with whom he was having an affair. Woods resigned from Parliament and subsequently received an 18-month suspended jail sentence. ${ }^{34}$ While impending court proceedings may pressure members to resign or retire from Parliament, including in circumstances where allegations are later proven to be baseless, such proceedings are not always an effective and efficient mechanism for holding members to account while they remain in Parliament.

\footnotetext{
${ }^{29} R v$ Theophanous [2003] VSCA 78 (20 June 2003); 'Theophanous Released from Prison' The Age (Melbourne, 5 February 2004) <http://www.theage.com.au/articles/2004/02/05/1075854002401.html > accessed 22 September 2012.

${ }^{30} R v$ Theophanous [2003] VSCA 78 (20 June 2003); 'Theophanous Released from Prison' (n 29).

31 See Dennis Woodward, 'Political Parties and Party System' in Andrew Parkin, John Summers and Dennis Woodward (eds), Government, Politics, Power and Policy in Australia (Pearson Education Australia 2006) 180, $180,185$.

32 Daryl Williams, Attorney-General and Minister for Justice (Cth), 'Senator Mal Colston' (Press Release, 15 July 1997). See also Malcolm Saunders and Neil Lloyd, "The Evolution of a Disgraced Politician: "Mal" Colston 1938-2003' (2011) 21 Queensland History Journal 397, 406-407.

${ }^{33}$ Saunders and Lloyd (n 32) 408-409.

34 Max Blenkin, 'Australian Political Sex Scandals' The Sydney Morning Herald (Sydney, 4 July 2002) $<$ http://www.smh.com.au/articles/2002/07/04/1025667032768.html> accessed 22 September 2012.
} 
Further, judicial proceedings may not be suited for determining what are essentially political questions. While a court is generally the most appropriate forum to resolve allegations of sexual harassment, like those raised against Peter Slipper, court proceedings may be used as a forum for political attacks, undermining the judicial process and public faith in parliamentarians. In the civil case against Slipper, Rares J stated that: 'Mr Ashby's predominant purpose for bringing these proceedings was to pursue a political attack against Mr Slipper and not to vindicate any legal claim he may have for which the right to bring proceedings exists ${ }^{35}$ with the goal of 'causing significant public, reputational and political damage to Mr Slipper.' ${ }^{36}$ By the time the civil proceedings were dismissed in December 2012, significant political and reputational damage had already been done to Slipper, the Australian Labor Party and Parliament more generally. ${ }^{37}$

\section{Disqualification}

In exceptional cases, misconduct by members of Parliament may also be subject to $\mathrm{s} 44$ of the Australian Constitution, which relevantly provides that an individual who:

(ii.) Is attainted of treason, or has been convicted and is under sentence, or subject to be sentenced, for any offence punishable under the law of the Commonwealth or of a State by imprisonment for one year or longer: or

(iii.) Is an undischarged bankrupt or insolvent: ...

shall be incapable of being chosen or of sitting as a senator or a member of the House of Representatives.

Under s 45 of the Australian Constitution, if a sitting Senator or member of the House of Representatives becomes subject to any of the provisions of s 44 , their seat becomes vacant. Further, under s 3 of the Common Informers (Parliamentary Disqualifications) Act 1975 (Cth), anyone who sits while disqualified is liable to pay $\$ 200$, plus another $\$ 200$ for every day the

\footnotetext{
${ }^{35}$ Ashby v Commonwealth (No 4) [2012] FCA 1411 (12 December 2012) para 196.

${ }^{36}$ Ibid para 197.

${ }^{37}$ See, for example, Lenore Taylor, 'Peter Slipper and the High Price of Rushed Judgment' The Sydney Morning Herald (Sydney, 12 December 2012) <http://www.smh.com.au/opinion/politics/peter-slipper-and-the-high-priceof-rushed-judgment-20121212-2b8rh.html> accessed 5 February 2013.
} 
disqualified person has sat after the case is filed, to any person who sues for it in a court of competent jurisdiction.

According to Carney, these grounds of disqualification are intended to secure the integrity of members of Parliament to ensure they perform their parliamentary functions in the interests of their constituency and, ultimately, the public interest. ${ }^{38}$ As a result, the disqualification provisions help to promote public confidence in Parliament and protect the integrity of Parliament itself. ${ }^{39}$

Section 44 has been extensively criticised for failing to reflect the needs of the modern Parliament, both for being too broad and so unnecessarily excluding some candidates, and for being too narrow in failing to exclude others. ${ }^{40}$ During the 1891 and $1897-98$ conventions that drafted the Australian Constitution, the delegates recognised the potential limitations of the disqualification provisions - it was clear that not all undesirable candidates would be excluded by their terms. As noted by Joseph Carruthers in the 1897-98 debates:

[If] hon. members will look at the clause, they will see that a man may be an habitual drunkard; he may have been convicted of misdemeanour time after time; he may be a thief or a criminal; but he is not, however, disqualified from a seat in parliament unless he is a felon. ${ }^{41}$

Indeed, the effect of s 44(ii) was that 'the greatest criminal under heaven is eligible, at the end of his sentence, to be a member of the Federal Legislature', ${ }^{42}$ it being assumed that once the sentence had been served the individual had 'atoned for his offence' ${ }^{43}$ Further, delegates recognised the difficulties of relying on the criminal law as a means of managing members'

\footnotetext{
${ }^{38}$ Gerard Carney, Members of Parliament: Law and Ethics (Prospect 2000) 15.

${ }^{39}$ Ibid.

${ }^{40}$ See, for example, Senate Standing Committee on Constitutional and Legal Affairs, Parliament of Australia, The Constitutional Qualifications of Members of Parliament (1981).

${ }^{41}$ Official Record of the Debates of the Australasian Federal Convention, Sydney, 21 September 1897, 1016 (Joseph Carruthers). See also Official Record of the Debates of the Australasian Federal Convention, Melbourne, 7 March 1898, 1933 (Joseph Carruthers), 1934-35 (George Reid).

42 Official Record of the Debates of the Australasian Federal Convention, Melbourne, 7 March 1898, 1934 (George Reid). See also Nile v Wood (1988) 167 CLR 133; Official Record of the Debates of the Australasian Federal Convention, Sydney, 24 September 1897, 1096-97 (Sir John Forrest, Edmund Barton).

${ }^{43}$ See Official Record of the Debates of the Australasian Federal Convention, Sydney, 24 September 1897, 1097 (Edmund Barton).
} 
misconduct - while members may be convicted under the criminal law, this could take a long period of time, and potentially extend beyond the re-election of the member. ${ }^{44}$

Despite these limitations, there was a general reluctance in the convention debates to increase the grounds of disqualification in the Constitution, noting that 'Parliament should [generally] regulate its own procedure' 45 rather than the 'Convention attempting to legislate for the people of the commonwealth'. ${ }^{46}$ Hence, it was intended that the Parliament should be able to add to the grounds of disqualification 'as fraud multiplies' ${ }^{47}$ by utilising ss 49 and 50 of the Constitution to legislate as to the privileges and responsibilities of members. ${ }^{48}$

The federal Parliament has added a limited number of statutory grounds of disqualification to those contained in the Australian Constitution. Section 386 of the Commonwealth Electoral Act 1918 (Cth) provides that any person convicted of bribery or interference with political liberty, or who is found by the Court of Disputed Returns to have committed or attempted to commit bribery or undue influence while a candidate for office, is incapable of 'being chosen or sitting' as a member of Parliament for two years from the date of the conviction or finding. That Act also states that individuals of 'unsound mind' who cannot understand the nature and significance of voting and people who have been convicted of treason or treachery and who have not been pardoned are excluded from the electoral roll and, as a result, are ineligible to be elected to Parliament. ${ }^{49}$

Section 44 has had limited apparent impact in regulating the misconduct of members of Parliament - indeed, s 44(ii) and (iii) have never been applied. ${ }^{50}$ However, the provision is effective in the sense of deterring ineligible candidates from standing for election. The possibility of disqualification acts as an incentive for political parties to vet their candidates

\footnotetext{
${ }^{44}$ Official Record of the Debates of the Australasian Federal Convention, Melbourne, 7 March 1898, 1938 (Sir John Forrest, William Lyne).

${ }^{45}$ Official Record of the Debates of the Australasian Federal Convention, Adelaide, 17 April 1897, 746 (Josiah Symon).

${ }^{46}$ Official Record of the Debates of the Australasian Federal Convention, Sydney, 21 September 1897, 1007 (Edmund Barton). See also Official Record of the Debates of the Australasian Federal Convention, Sydney, 21 September 1897, 1027 (Henry Higgins). Cf Official Record of the Debates of the Australasian Federal Convention, Sydney, 21 September 1897, 1007-1008 (John Gordon).

${ }^{47}$ Official Record of the Debates of the Australasian Federal Convention, Sydney, 21 September 1897, 1027 (Henry Higgins).

${ }^{48}$ For further discussion of the history of s 44, see John Williams, The Australian Constitution: A Documentary History (Melbourne University Press 2005).

${ }^{49}$ Commonwealth Electoral Act 1918 (Cth) ss 93(8), 163.

${ }^{50}$ However, both ss 44(ii) and (iii) were raised and rejected in Nile v Wood (1987) 76 ALR 91.
} 
carefully before nomination. As a result, there may be little need for the courts and Parliament to enforce s 44(ii) and (iii). Further, s 44 encourages sitting members of Parliament to resign their seat or retire prior to becoming disqualified ${ }^{51}$ or to avoid breaching the provisions at all. ${ }^{52}$ While s 44 influences the behaviour of potential candidates and members of Parliament, its lack of visible impact has led to it being described as 'rudimentary at best' in acting as a code of conduct and regulating behaviour..$^{53}$

In some circumstances, political partisanship may explain the lack of use of s 44 . Under s 376 of the Commonwealth Electoral Act 1918 (Cth), questions of qualification may be 'referred by resolution' of either house of Parliament to the High Court of Australia (sitting as the Court of Disputed Returns) for determination. ${ }^{54}$ However, this mechanism is rarely used. In 1999, the federal Opposition alleged that Warren Entsch, parliamentary secretary to the Minister for Industry, was disqualified under s $44(\mathrm{v})$ due to his interest in a private company that had won a government contract. Rather than referring the issue to the High Court for determination, the government majority in the House of Representatives purported to deal with the issue by passing a resolution that Entsch did not 'have any direct or indirect pecuniary interest with the Public Service of the Commonwealth ... by reason of any contract entered into by Cape York Concrete' and was therefore not disqualified from sitting in the House of Representatives. ${ }^{55}$ Similarly, on 5 May 1977, the House of Representatives defeated a motion to refer to the Court of Disputed Returns a matter involving a possible benefit derived by MP Michael Baume from a deed of arrangement under Part X of the Bankruptcy Act 1966 (Cth). The House decided on party lines not to refer the matter to the Court for determination. ${ }^{56}$ These instances demonstrate how the efficacy of s 44 may be constrained by partisan factors.

\footnotetext{
${ }^{51}$ For example, in 1998, Michael Cobb retired from Parliament weeks before receiving a two year suspended sentence after being found guilty of imposing on the Commonwealth and fraud. Robert Woods resigned from the Senate on 7 March 1997, shortly before being sentenced in June 1999 on charges of defrauding the Commonwealth. Finally, Mal Colston retired from Parliament on 30 June 1999 while facing the prospect of criminal charges. See Bob Bennett, 'Candidates, Members and the Constitution' (Research Paper No 18, Parliamentary Library, Parliament of Australia 2002).

${ }^{52}$ For example, in 2009 Senator Bob Brown was threatened with bankruptcy following a court order to pay Forestry Tasmania's legal costs of AUD $\$ 240,000$. Following a public appeal, sufficient money was raised to satisfy the order. See Bob Brown, 'Forestry Tasmania's Bill Will be Paid on Time, Says Brown' (Media Release, 11 June 2009).

${ }^{53}$ Bennett (n 51).

${ }_{54}^{54}$ See Australian Constitution s 47.

${ }^{55}$ Commonwealth, Parliamentary Debates, House of Representatives, 10 June 1999, 6724 (Daryl Williams, Attorney-General).

${ }^{56}$ Commonwealth, Parliamentary Debates, House of Representatives, 5 May 1977, 129-38; Senate Standing Committee on Constitutional and Legal Affairs, Parliament of Australia, The Constitutional Qualification of Members of Parliament (1981) 31-34.
} 
Section 44 and other statutory grounds of disqualification are blunt mechanisms for dealing with misconduct by members of Parliament. They have limited scope, and may be overborne by the political self-interest evident in the highly contested and partisan nature of many misconduct allegations. In this context, disqualifying members of Parliament as a way of managing misconduct will often be an inflexible and ineffective mechanism. As a result, extending the grounds of disqualification is unlikely to be a useful means of meeting any demand for enhanced accountability.

\section{PARLIAMENTARY ACCOUNTABILITY MECHANISMS}

\section{A Parliamentary Privilege}

Westminster Parliaments have traditionally held members to account through the use of parliamentary privilege, that is, the rights and immunities possessed by the houses of Parliament to enable them to effectively carry out their functions. ${ }^{57}$ The right of the houses of Parliament to regulate their own internal affairs was historically asserted as a means of protecting Parliament from the intervention of 'an overly mighty executive'. ${ }^{58}$ However, this 'exclusive cognisance' is now better viewed as a reflection and manifestation of parliamentary sovereignty. ${ }^{59}$ It enables Parliament to regulate its own affairs and composition, which includes the power to discipline its members for misconduct. ${ }^{60}$ Parliament may admonish, suspend, imprison or, in serious cases, expel its members for misbehaviour. ${ }^{61}$ Upon federation, the Australian federal Parliament was vested with the powers, privileges, and immunities of the UK House of Commons, including the power to discipline its members. Section 49 of the Australian Constitution reads:

\footnotetext{
${ }^{57}$ Joint Committee on Parliamentary Privilege, Parliamentary Privilege (first report) (1998-99, HL 43, HC 214) para 3; Gareth Griffith, 'Parliamentary Privilege: First Principles and Recent Applications' (Briefing Paper No 1/09, Parliamentary Library, NSW Parliament 2009) 1, 6.

${ }^{58}$ Office of the Leader of the House of Commons, Parliamentary Privilege $(\mathrm{Cm} 8318,2012)$ para 26.

${ }^{59}$ Ibid.

${ }^{60}$ Joint Committee on Parliamentary Privilege (n 57) para 14; Malcolm Jack et al (eds), Erskine May Parliamentary Practice (24th edn, LexisNexis 2011) 203.

${ }^{61}$ Caroline Morris, 'Misbehaving Members of Parliament and How to Deal with Them' in J Boston, P Butler and C Morris (eds), Reconstituting the Constitution (Springer Publishing 2011) 1, 7. See also Armstrong v Budd (1969) 71 SR (NSW) 386, 403 (Wallace P).
} 
The powers, privileges, and immunities of the Senate and of the House of Representatives, and of the members and the committees of each House, shall be such as are declared by the Parliament, and until declared shall be those of the Commons House of Parliament of the United Kingdom, and of its members and committees, at the establishment of the Commonwealth.

Parliament was also given the power to regulate parliamentary privilege by s 50 of the Constitution:

Each House of the Parliament may make rules and orders with respect to -

(i.) The mode in which its powers, privileges, and immunities may be exercised and upheld:

(ii.) The order and conduct of its business and proceedings either separately or jointly with the other House.

The powers vested under s 49 remained relatively unchanged until the passing of the Parliamentary Privileges Act 1987 (Cth), which codified some aspects of parliamentary privilege in accordance with s 50 of the Australian Constitution.

While the Australian federal Parliament is vested with significant powers to enforce the discipline of its own members, they have been rarely used. Indeed, the power to expel has only been used once. ${ }^{62}$ In 1920, Hugh Mahon was expelled from the House of Representatives for 'seditious and disloyal utterances', which constituted 'conduct unfitting' for a member of the House. ${ }^{63}$ The accusations concerned a public speech in Melbourne in which Mahon expressed sympathy for Irish Republicans and opposition to British policy in Ireland. However, it was unclear exactly what was said at the meeting. ${ }^{64}$ Mahon was expelled following a vote along party lines. ${ }^{65}$

\footnotetext{
${ }^{62}$ Enid Mona Campbell, Parliamentary Privilege (Federation Press 2003) 209.

${ }^{63}$ Commonwealth, Parliamentary Debates, House of Representatives, 11 November 1920, 6382-89 (William Hughes, Prime Minister); Joint Select Committee on Parliamentary Privilege, Parliament of Australia, Final Report, Parliamentary Paper No 219 (1984) 126.

${ }^{64}$ Joint Select Committee on Parliamentary Privilege (n 63) 126.

${ }^{65}$ Ibid 127.
} 
In its 1984 report, the Joint Select Committee on Parliamentary Privilege recommended that the power to expel members of Parliament be abolished given the risk of the power being abused by a party enjoying a majority of members in a house. ${ }^{66}$ The Committee believed that the disqualification provisions in the Australian Constitution (discussed at Part IIC above) would accommodate most instances in which a Parliament might wish to expel one of its members. ${ }^{67}$ Further, it was for the electorate, not the Parliament, to determine who should be their representative, and it would be 'wrong' for Parliament to be able to overrule that decision. ${ }^{68}$ Finally, the Committee noted that there were other ways in which the Parliament could discipline its members - these powers were 'drastic enough' without also having the power to expel. ${ }^{69}$ Following the Committee's recommendations, the power to expel was abolished by s 8 of the Parliamentary Privileges Act 1987 (Cth), which states: 'A House does not have power to expel a member from membership of a House.'

Other aspects of parliamentary privilege remain intact following passage of the Parliamentary Privileges Act. ${ }^{70}$ The Act empowers the Parliament to impose fines of up to $\$ 5,000$ for individuals and $\$ 25,000$ for corporations for offences 'against the House' ${ }^{71}$ defined as being 'improper interference with the free exercise by a House or committee of its authority or functions, or with the free performance by a member of the member's duties as a member' ${ }^{72}$ While this power undoubtedly provides Parliament with a new form of recourse, the narrow definition of 'offences against the House' means it is unlikely to assist with resolving many cases of misconduct by members of Parliament. Indeed, the provisions have not been used by either House. It is also unclear whether the Parliamentary Privileges Act has limited any separate power held by Parliament to suspend to conduct which amounts to an 'offence against the House' ${ }^{73}$

Parliamentary privilege is also regulated by the standing orders of each House. In the House of Representatives, Standing Orders 51 and 52 provide for the making of motions declaring that a contempt or breach of privilege has been committed and the referral of matters to the

\footnotetext{
66 Ibid 128.

${ }^{67}$ Ibid.

${ }^{68}$ Ibid.

${ }^{69}$ Ibid.

${ }^{70}$ See, for example, Parliamentary Privileges Act 1987 (Cth) s 5.

${ }^{71}$ Ibid s 7(5).

72 Ibid s 4.

${ }^{73}$ Campbell, Parliamentary Privilege (n 62) 211-12.
} 
Committee of Privileges and Members' Interests. The Committee is responsible for inquiring into and reporting on complaints of breach of privilege or contempt referred to it by the House or the Speaker. The Committee's role is to investigate and advise, recommending to the House what action, if any, should be taken in a given case.

In practice, the Committee plays a very limited role in cases of parliamentary misconduct. In the $42^{\text {nd }}$ and $43^{\text {rd }}$ Parliaments (spanning 2008 to 2013), only two matters of parliamentary misconduct have been referred to the Committee for inquiry. The first matter referred to the Committee related to 'the issue of the exchange between the Member for Robertson and the Member for Indi on 28 May 2008 and the subsequent withdrawal and apology by the Member for Robertson on 29 May 2008'. In that case, the Member for Robertson, Belinda Neal, allegedly commented to the Member for Indi, Sophie Mirabella (who was heavily pregnant), that '[e]vil thoughts will turn your child into a demon'. ${ }^{74}$ When the Speaker requested that the Member for Robertson withdraw the comment, she claimed that she had not made the comment and so refused to withdraw it. The Speaker again requested that the comment be withdrawn and the Member for Robertson again denied that the comment had been made. The next morning in Parliament, the Member for Robertson 'unreservedly [withdrew] any remarks that may have caused offence to the Member [for Indi]. ${ }^{, 75}$

In its report on the incident, the Committee noted that ' $[\mathrm{t}]$ he only potential matter of privilege ... is a question of possible deliberate misleading of the House by the Member for Robertson in denying that she made certain statements in the Main Committee.' While the exchange did not satisfy the strict definition of deliberately misleading the House, and therefore did not amount to an issue of privilege, the Committee was of the opinion that 'the terms used by the Members and the tenor of the exchange [fell] below the standards expected of members and do not reflect well upon them. ${ }^{76}$ The inquiry

[raised] issues ... more to do with appropriate standards of behaviour and conduct of members, than to do with matters of privilege. While the standing orders cover most aspects of the behaviour of members when they are in the Chamber and Main

\footnotetext{
${ }^{74}$ House of Representatives Standing Committee of Privileges and Members' Interests, Parliament of Australia, Report on the Issue of the Exchange between the Member for Robertson and the Member for Indi on 28 May 2008 and the Subsequent Withdrawal and Apology by the Member for Robertson on 29 May 2008 (2008) 1.

${ }^{75}$ Ibid 2.

${ }^{76}$ Ibid 8.
} 
Committee and can be used to enforce appropriate standards of behaviour, there is no broader code of conduct to cover the conduct of members generally. ${ }^{77}$

As a result, there was little the Committee could do in relation to the exchange between the Member for Robertson and the Member for Indi.

Second, in relation to the Thomson affair, the Committee has been asked to examine whether Thomson 'deliberately misled the House' in his speech in the House in response to the Fair Work Australia report. ${ }^{78}$ While the Committee has not been asked to determine whether Thomson is guilty of misconduct, Thomson's denial of any misbehaviour in Parliament is likely to lead to such questions being raised in the Committee's proceedings. As a result, the inquiry may raise complex questions of fact and law that may soon come before the courts. Further, it is possible that the Committee will divide along party lines, thereby reducing the degree to which it may effectively scrutinise Thomson's conduct. ${ }^{79}$

Unlike the Standing Orders in the House of Representatives, the Senate has passed a number of resolutions which provide substantive guidance in relation to matters of contempt and privilege. These establish that the Senate should only use its powers in relation to contempt 'where it is necessary to provide reasonable protection for the Senate and its committees and for senators against improper acts tending substantially to obstruct them in the performance of their functions' ${ }^{80}$ Further, Resolution 6 provides guidance as to the type of conduct that may constitute contempt. The areas identified in Order 6 relate to interference with the conduct of Senate proceedings, and, as a result, do not deal directly with misconduct by members. However, Resolution 6(3) does specify that:

A senator shall not ask for, receive or obtain, any property or benefit for the senator, or another person, on any understanding that the senator will be influenced in the discharge of the senator's duties, or enter into any contract, understanding or arrangement having the effect, or which may have the effect, of controlling or limiting

\footnotetext{
77 Ibid 9.

78 See Commonwealth, Parliamentary Debates, House of Representatives, 21 May 2012, 4715-23 (Craig Thomson); Commonwealth, Parliamentary Debates, House of Representatives, 22 May 2012, 5063-65.

${ }^{79}$ Paul Kelly, 'Thomson Saga Shows Minority Government's Flaws' The Australian (Sydney, 26 May 2012 ) 13.

${ }^{80}$ Commonwealth, Parliamentary Privilege: Resolutions Agreed to by the Senate on 25 February 1988 (1988) resolution 3(a).
} 
the senator's independence or freedom of action as a senator, or pursuant to which the senator is in any way to act as the representative of any outside body in the discharge of the senator's duties.

In the Senate, the Standing Committee of Privileges fulfils a similar role to the Standing Committee of Privileges and Members' Interests in the House of Representatives. The Senate Committee's role is to 'inquire into and report upon matters of privilege referred to it by the Senate' ${ }^{81}$ In conducting inquiries into misconduct, the Committee is generally concerned with ascertaining whether an offence against the house has occurred in accordance with the definition in the Parliamentary Privileges Act. ${ }^{82}$ Between 2008 and 2012, only two inquiries by the Committee have related to misconduct by Senators.

The first case related to the OzCar scandal of 2009, in which Treasury official Godwin Grech falsely accused Ministers of acting improperly on behalf of a Queensland car dealer seeking financial assistance from a government agency. In the course of investigating Godwin Grech's behavior the Committee was asked to inquire into:

whether there was any pre-arrangement of questions and answers for the hearing [of the Economics Legislation Committee on 22 June 2009 by Malcolm Turnbull and Senator Abetz with Godwin Grech] and, if so, whether this constituted an improper interference with the hearing. ${ }^{83}$

The Committee found that 'there was no inappropriate pre-arrangement of questions and answers for the hearing' and that there was 'no evidence that either [Mr Turnbull or Senator Abetz] took Mr Grech at anything other than face value in acting in good faith on the information provided by him. ${ }^{\text {'84 }}$

In the second case, allegations were raised in 2011 that Senator Bob Brown had entered into an arrangement under which he and other senators agreed to limit their independence in the

\footnotetext{
${ }^{81}$ Rosemary Laing (ed), Annotated Standing Orders of the Australian Senate (Department of the Senate 2009) order 18.

${ }^{82}$ Senate Committee of Privileges, Parliament of Australia, 142nd Report: Matters Arising from the Economics Legislation Committee Hearing on 19 June 2009 (Referred 24 June and 12 August 2009) (2009) 85-86.

${ }^{83}$ Ibid 73.

${ }^{84}$ Ibid 76.
} 
discharge of their duties in return for the Australian Greens receiving political donations. ${ }^{85}$ In its report, the Committee noted the rarity and difficulty of being asked to adjudicate misconduct by Senators, particularly given it might require the Committee to 'prefer one senator's account over another's'. ${ }^{86}$ The Committee took a conservative view of its role in investigating misconduct:

in the absence of persuasive evidence to the contrary, the committee would have no cause to dispute an account given by a senator of matters within his or her own personal knowledge. This is consistent with the approach the committee has previously taken in relation to allegations involving senators. ${ }^{87}$

Given there was no persuasive evidence contrary to Senator Brown's account, the Committee held that no issue of contempt arose on the material before it. ${ }^{88}$

These cases in the House of Representatives and Senate Committees illustrate the challenge of relying on parliamentary privilege to manage members' misconduct: cases of misconduct are often not matters of parliamentary privilege ${ }^{89}$ As a result, it is difficult, if not impossible, for the privileges committees and Parliament to deal with some forms of misconduct under existing measures. For example, the accusations against Thomson and Slipper do not raise matters of parliamentary privilege, except to the extent Parliament may have been misled by the members themselves. Noting this limitation and its own limited effectiveness in dealing with members' misconduct, in 2008 the House of Representatives Standing Committee of Privileges and Members' Interests renewed the call for a parliamentary Code of Conduct. ${ }^{90}$

The use of parliamentary privilege may also be limited by political partisanship: imposition of a penalty through parliamentary privilege requires the support of the House. As a result, there is a risk that the government will protect its own members from scrutiny and impose more

\footnotetext{
85 Senate Committee of Privileges, Parliament of Australia, 150th Report: Whether There was Any Improper Influence in Relation to Political Donations Made by Mr Graeme Wood and Questions Without Notice Asked by Senator Bob Brown and Senator Milne (2012) i.

${ }^{86}$ Ibid 2.

${ }^{87}$ Ibid 9.

${ }^{88}$ Ibid 12.

${ }^{89}$ See, for example, House of Representatives Standing Committee of Privileges and Members' Interests, Report on the Issue of the Exchange between the Member for Robertson and the Member for Indi (n 74) 9.

${ }^{90}$ Ibid 10.
} 
severe penalties on members of the opposition. ${ }^{91}$ The often partisan nature of parliamentary privilege motions may also limit their usefulness in regulating the behaviour of members of Parliament.

Given these considerations, it is unsurprising that parliamentary privilege has been rarely used to manage misconduct by members of Parliament. Table 1 below demonstrates the limited number of times parliamentary privilege has been used against members of Parliament since federation.

Table 1: Use of Parliamentary Privilege against Members of Federal Parliament 19012013

\begin{tabular}{|c|c|c|c|}
\hline Measure & Dates used & Member & Misconduct \\
\hline Admonish & Not used..$^{92}$ & & \\
\hline Fine & Not used. ${ }^{93}$ & & \\
\hline Suspend $^{94}$ & 1913 & Charles McGrath & $\begin{array}{l}\text { '[U]nbecoming and insulting } \\
\text { conduct to the Chair'; }{ }^{95} \text { made public } \\
\text { comments alleging the Speaker had } \\
\text { lost the confidence of the House and } \\
\text { deliberately altered a Hansard } \\
\text { proof; } 96 \text { suspended for the rest of } \\
\text { the session. } \\
\text { Suspension expunged in next } \\
\text { Parliament for 'being subversive of }\end{array}$ \\
\hline
\end{tabular}

${ }^{91}$ Bennett (n 51); Campbell, Parliamentary Privilege (n 62) 209.

92 I C Harris (ed), House of Representatives Practice (5th edn, Department of the House of Representatives 2005) $742-43$.

${ }^{93}$ However, the Senate Committee of Privileges has recommended that the person responsible for disclosing in camera documents be fined 'if ever discovered': Senate Committee of Privileges, Parliament of Australia, Possible Unauthorised Disclosure of a Submission to the Parliamentary Joint Committee on Corporations and Securities (2001) 18.

${ }^{94}$ Note that it is not uncommon for members of Parliament to be suspended as a matter of order (as opposed to a matter of privilege) - indeed, a search of House of Representatives votes and proceedings revealed 270 motions that a member be suspended from the House for disorderly conduct between 1910 and 2012. See House of Representatives Standing Orders 91, 94; Senate Standing Orders 203, 204.

95 'Latest Telegrams. Federal Parliament' Northern Territory Times and Gazette (Darwin, 20 November 1913$) 3$.

96 'Parliamentary Turmoil. Members and the Speaker. Allegations of Unfairness. Suspension of Mr. Thomas. Mr. Mcgrath Suspended for Session.' The Argus (Melbourne, 12 November 1913) 17. 


\begin{tabular}{|c|c|c|c|}
\hline & & & $\begin{array}{l}\text { the right of an honourable Member } \\
\text { to freely address his constituents' }{ }^{97}\end{array}$ \\
\hline & 1987 & Wilson Tuckey & $\begin{array}{l}\text { Made comments that were critical } \\
\text { of the Speaker outside of } \\
\text { Parliament; suspended for } 7 \text { sitting } \\
\text { days. }{ }^{98}\end{array}$ \\
\hline & 1989 & Ken Aldred & $\begin{array}{l}\text { Refused to apologise and withdraw } \\
\text { allegations made in Parliament as } \\
\text { recommended by Privileges } \\
\text { Committee report; suspended for } 2 \\
\text { sitting days.99 }\end{array}$ \\
\hline Imprison & Not used. & & \\
\hline Expel & 1920 & Hugh Mahon & $\begin{array}{l}\text { '[S]editious and disloyal } \\
\text { utterances' (discussed above). }\end{array}$ \\
\hline
\end{tabular}

\section{LiMITATIONS AND GAPS IN EXISTING ACCOUNTABILITY MECHANISMS}

As the foregoing analysis demonstrates, while a range of accountability mechanisms for misconduct are already in place in the Australian federal Parliament, the system has a number of gaps. The accountability of parliamentarians to the people at periodic elections is a vital part of the system of representative government, but is an inadequate means of dealing with misconduct. It is impossible to discern the extent to which misconduct influences a person's voting intention, which may be affected by a broad range of factors that extend far beyond the actions of the individual member.

Misconduct may be addressed through parliamentary privilege and investigated by the Privileges Committee of the relevant house of Parliament. However, parliamentary privilege does not encompass many forms of misconduct, including personal misconduct that may impinge on a member's performance of their parliamentary duties or undermine public

\footnotetext{
${ }^{97}$ Commonwealth, Parliamentary Debates, House of Representatives, 26 June 1914, 101 (William Maloney).

${ }^{98}$ Paul Osborne, 'Thomson Under Pressure to Explain Fully' The Sydney Morning Herald (Sydney, 10 May 2012)

$<$ http://news.smh.com.au/breaking-news-national/thomson-under-pressure-to-explain-fully-201205101ydj3.html $>$ accessed 22 September 2012.

${ }_{99}$ Commonwealth, Parliamentary Debates, House of Representatives, 21 December 1989, 3353-78.
} 
confidence in Parliament. Further, political factors may limit the effectiveness of parliamentary privilege as an accountability mechanism.

In exceptional cases, s 44 of the Constitution may provide a means of addressing misconduct if the behaviour falls within the narrow confines of the section. However, as noted above, it is very rare for this to be the case. In particular, misconduct often falls short of criminal behaviour and, even if the behaviour is criminal, s 44 will only operate once the member has been through the court system and a conviction has been recorded. Relying on the court system to secure accountability for misconduct is often a long-term process, sometimes taking years to complete. While Thomson and Slipper have both been subject to civil and criminal proceedings, only one action has been resolved in early 2013 - nearly a year after the allegations first emerged.

Overall, the system to manage misconduct has major gaps, including the absence of an effective mechanism for securing short-term accountability for misconduct by members of Parliament or for addressing many forms of personal misconduct that fall short of a criminal offence. There is also no means of addressing non-criminal conduct that occurred prior to members entering Parliament, but which has the potential to undermine public confidence in Parliament.

These limitations mean that many instances of misconduct, rather than being managed via a specific mechanism, tend to be played out in an ad hoc manner in the federal Parliament and media, often in a way that enhances public distrust of politicians and public institutions while not actually resolving the underlying issue. This is demonstrated in the Thomson case: in the weeks and months following the release of the Fair Work Australia report, Thomson's alleged behaviour was extensively criticised in the media and in Parliament, to the point where some feared for Thomson's wellbeing. ${ }^{100}$ The conduct of the politicians involved in this debate has been variously described as 'low and dirty', 'childish or amateurish', ${ }^{101}$ 'grubby', 102 'getting into the gutter', ${ }^{103}$ a 'high farce' ${ }^{104}$ and 'a very low point in politics'. ${ }^{105}$ Others raised concerns that the process was having a 'corrosive effect' on democracy due to a growth in distrust of

\footnotetext{
100 Shanahan (n 5); Taylor, 'Political Feeding Frenzy a Plague on Both Houses' (n 11).

${ }^{101}$ John Slack-Smith, Letter to the Editor The Chronicle (Toowoomba, 6 July 2012) 37.

102 Peter van Onselen, 'House's Dirty Deeds' The Australian (Sydney, 15 June 2012) 11.

103 Shanahan (n 5).

${ }^{104}$ Hudson (n 7).

105 Ibid.
} 
politicians ${ }^{106}$ and noted that 'public standing of Parliament and politicians is in dramatic decline and public confidence in the democratic system in crumbling'. ${ }^{107}$ According to Independent MP Rob Oakeshott, the Thomson affair caused 'significant damage both short and long term with regard to public confidence and public trust in the Australian Parliament itself'. ${ }^{108}$ This lack of trust is reflected in the World Economic Forum's 2012-13 Global Competitiveness Report: of the 144 countries surveyed, Australia was ranked 27th in relation to the level of public trust in the ethical standards of politicians, behind countries like China, Malaysia and Gambia. ${ }^{109}$

The handling of parliamentary misbehavior in such a public and political manner can have serious consequences for the wellbeing of the individual concerned, their entitlement to the presumption of innocence, ${ }^{110}$ the electoral fortunes of the political party they belong to ${ }^{111}$ and the integrity and reputation of Parliament itself. Further, this may occur in a way that produces these serious repercussions without determining whether in fact the allegation of misconduct that sparked the debate has merit. The ultimate outcome for the individual may be determined in a haphazard manner, often as a result of political pressure rather than the testing of the claims made against them. Such factors have been especially prominent in the case of Thomson. A number of commentators have argued that Thomson was subjected to a disproportionate level of scrutiny and criticism as he essentially held the balance of power in a minority government. ${ }^{112}$ This is consistent with Harris's argument that the 'theatre of deception' surrounding political scandals means minor scandals often become a source of public fascination, leading to politicians being dealt with overly severely. ${ }^{113}$

While this is clearly not an ideal state of affairs, it does not necessarily imply that Parliament should be further empowered to manage misconduct by its members. It may simply mean that, imperfect as it is, this system is the best available, or that developing additional mechanisms may actually make the problem worse. This reflects the significant institutional and political

\footnotetext{
106 Amanda Lohrey, 'Comment: Australian Democracy and the Right to Party' The Monthly (Melbourne, 1 July 2012). 
limitations of Parliament. Oliver has recognised this in arguing that, for a system of parliamentary self-regulation to operate effectively, it should demonstrate:

- a genuine commitment by members to upholding standards of conduct;

- (merited) public confidence in the system of self-regulation;

- a degree of external involvement;

- separation or independence from members whose interests may be affected;

- clear standards of conduct;

- appropriate sanctions;

- responsiveness to changing social expectations and standards; and

- effective public accountability. ${ }^{114}$

By its nature, Parliament is a political body and its processes and procedures are inevitably subject to partisan politics. As a result, there is a risk that in any parliamentary mechanism the governing party will essentially regulate its own behaviour, ${ }^{115}$ seriously jeopardising the independence of and public confidence in the system. Further, Parliament is not well equipped to determine complex factual questions, such as those in the Thomson case, and has no (or very limited) experience in acting as an independent adjudicative body. Finally, there is evidence that politicians rarely agree on the standards of conduct that should accompany their position, making it difficult to create clear standards of behaviour for a system of self-regulation. ${ }^{116}$ As a result, it may often be inappropriate for Parliament to determine misconduct issues.

These factors justify caution when it comes to designing new methods by which Parliament may deal with the misconduct of its members. However, such caution does not justify inaction in the face of the gaps and limitations in the current system if alternate, effective methods of accountability exist. This is because weaknesses in the existing system of accountability itself poses major risks and dangers. In particular, public confidence may be threatened when serious misconduct on the part of elected representatives does not result in judicial repercussions or other forms of external scrutiny. Failing to hold members of Parliament accountable at all for their misconduct, or even to investigate such claims in the first place, has the potential to

\footnotetext{
${ }^{114}$ Dawn Oliver, 'Regulating the Conduct of MPs. The British Experience of Combating Corruption' in Paul Heywood (ed), Political Corruption (Blackwell 1997) 123, 123.

115 Enid Campbell, 'Adjudication of Parliamentary Offences' (2003) 22(2) The University of Queensland Law Journal 173, 175.

${ }^{116}$ Oliver (n 114) 131.
} 
significantly damage the integrity and reputation of Parliament and further cultivate public distrust of politicians.

Given these considerations, it may be desirable to establish further accountability mechanisms for managing parliamentary misconduct. However, apart from questions as to the effectiveness of such measures, other considerations can also arise. First, objections may be raised to an external judicial or quasi-judicial process on the grounds that it infringes the separation of powers and reduces the ability of Parliament to manage its own affairs. At the same time, Parliament is generally incapable of performing a judicial or quasi-judicial role itself.

Second, like any other citizen, members of Parliament are entitled to privacy in their personal and family life. ${ }^{117}$ It is not appropriate for Parliament and the public to intrude in every aspect of a member's life: any intrusion should be driven by a clear public interest and limited to what is necessary and proportionate. ${ }^{118}$ As a result, any accountability mechanism should be limited in the extent to which it can investigate and intrude into non-parliamentary conduct. Parliamentary accountability mechanisms should be directed only to misconduct relating to a person's membership of Parliament.

\section{INTERNATIONAL COMPARATORS}

Given these challenges, it is useful to consider how the conduct of members of Parliament is managed in comparative jurisdictions. Systems for managing conduct tend to include some or all of the following elements: political repercussions, such as being demoted or resigning from cabinet, or losing party endorsement; 'soft' internal regulation, including codes of conduct that lack a power of sanction; 'hard' internal regulation through the law of parliamentary privilege; and external regulation through an independent standards authority (that is, a body independent of Parliament having some power to inquire into the conduct of its members). ${ }^{119}$ Table 2 below illustrates the mechanisms present in national Parliaments in Westminster systems.

\section{Table 2: Regulation of Behaviour for Members of Parliament in Westminster Systems}

\footnotetext{
${ }^{117}$ Parliamentary Commissioner for Standards, Annual Report 2011-12 (HC 2012-13, 311) 9.

118 Ibid.

${ }^{119}$ See Morris (n 61) 5.
} 


\begin{tabular}{|c|c|c|c|}
\hline Jurisdiction & $\begin{array}{c}\text { Parliamentary } \\
\text { Committee }\end{array}$ & Code of Conduct & $\begin{array}{c}\text { Independent } \\
\text { Standards Authority }\end{array}$ \\
\hline Australia & $\begin{array}{l}\text { Standing Committee of } \\
\text { Privileges and } \\
\text { Members' Interests } \\
\text { (House of } \\
\text { Representatives); } \\
\text { Standing Committee of } \\
\text { Privileges (Senate) }\end{array}$ & $\mathbf{x}$ & $\mathbf{x}$ \\
\hline United Kingdom & $\begin{array}{l}\text { Committee on } \\
\text { Standards (House of } \\
\text { Commons); Committee } \\
\text { on Privileges (House of } \\
\text { Commons); } \\
\text { Sub-Committee on } \\
\text { Lords' Conduct, } \\
\text { Committee for } \\
\text { Privileges and Conduct } \\
\text { (House of Lords) }\end{array}$ & $\begin{array}{l}\text { Code of Conduct } \\
\text { and Guide to the } \\
\text { Rules Relating to } \\
\text { the Conduct of } \\
\text { MPs (House of } \\
\text { Commons); } \\
\text { Code of Conduct } \\
\text { for the House of } \\
\text { Lords }\end{array}$ & $\begin{array}{l}\text { Independent } \\
\text { Parliamentary } \\
\text { Standards Authority }\end{array}$ \\
\hline Canada & $\begin{array}{l}\text { Standing Committee on } \\
\text { Procedure and House } \\
\text { Affairs (House of } \\
\text { Commons); } \\
\text { Standing Committee on } \\
\text { Conflict of Interest for } \\
\text { Senators (Senate); } \\
\text { Standing Committee on } \\
\text { Rules, Procedures and } \\
\text { the Rights of Parliament } \\
\text { (Senate) }\end{array}$ & $\begin{array}{l}\text { Conflict of } \\
\text { Interest Code for } \\
\text { Members of the } \\
\text { House of } \\
\text { Commons; } \\
\text { Conflict of } \\
\text { Interest Code for } \\
\text { Senators }\end{array}$ & $\begin{array}{l}\text { Conflict of Interest and } \\
\text { Ethics } \\
\text { Commissioner }^{120}\end{array}$ \\
\hline
\end{tabular}

${ }^{120}$ The Conflict of Interest and Ethics Commissioner is an Officer of Parliament, but operates independently of the government of the day: Parliament of Canada Act, RSC 1985, c P-1, ss 81-84. 


\begin{tabular}{|c|c|c|c|}
\hline Ireland & $\begin{array}{l}\text { Select Committee on } \\
\text { Members' Interests (in } \\
\text { each house); } \\
\text { Committee on } \\
\text { Procedure and } \\
\text { Privileges (in each } \\
\text { house) }\end{array}$ & $\begin{array}{l}\text { Code Of Conduct } \\
\text { For Members Of } \\
\text { Dáil Éireann } \\
\text { Other Than } \\
\text { Office Holders; } \\
\text { Code Of Conduct } \\
\text { For } \\
\text { Members Of } \\
\text { Seanad Éireann } \\
\text { Other Than } \\
\text { Office Holders }\end{array}$ & $\begin{array}{l}\text { Standards in Public } \\
\text { Office Commission }\end{array}$ \\
\hline New Zealand & Privileges Committee & $\mathbf{x}$ & $\mathbf{x}$ \\
\hline India & $\begin{array}{l}\text { Committee of } \\
\text { Privileges (in each } \\
\text { house); } \\
\text { Committee on Ethics } \\
\text { (in each house) }\end{array}$ & $\begin{array}{l}\text { Code of Conduct } \\
\text { for Members of } \\
\text { Rajya Sabha } \\
\text { (upper house) }\end{array}$ & $\mathbf{x}$ \\
\hline Pakistan & $\begin{array}{l}\text { Standing Committee of } \\
\text { Rules of Procedure \& } \\
\text { Privileges (in each } \\
\text { house) }\end{array}$ & $\mathbf{x}$ & $\mathbf{x}$ \\
\hline Malaysia & $\begin{array}{l}\text { Committee of } \\
\text { Privileges (in each } \\
\text { house) }\end{array}$ & $\mathbf{x}$ & $\mathbf{x}$ \\
\hline Singapore & $\begin{array}{l}\text { Committee of } \\
\text { Privileges }\end{array}$ & $\mathbf{x}$ & $\mathbf{x}$ \\
\hline
\end{tabular}

Table 2 demonstrates that most Westminster countries have parliamentary committees, often a Committee of Privileges or similar, to assist with managing the conduct of parliamentarians. 
However, codes of conduct and independent standards authorities are far less widespread. Two jurisdictions above that have adopted both these mechanisms - the United Kingdom and the Republic of Ireland - are considered in more detail below.

\section{A United Kingdom}

\section{Code of Conduct and Internal Regulation}

\section{(a) House of Commons}

Members of the House of Commons are subject to the Code of Conduct together with the Guide to the Rules Relating to the Conduct of Members, which has existed in various forms since 1996. The purpose of the Code is to assist members in discharging their obligations by establishing standards and principles of conduct, setting rules of conduct and, as a result, ensuring public confidence in the standards of Parliament. ${ }^{121}$ The Code includes seven general principles of conduct: selflessness, integrity, objectivity, accountability, openness, honesty and leadership. ${ }^{122}$ However, these principles are purely aspirational - infringing a principle is not sufficient of itself to warrant any form of sanction.

Following a review of the Code by the Parliamentary Commissioner for Standards in 2011, the House of Commons Standards and Privileges Committee noted that the Code of Conduct 'provided a valuable framework for parliamentary standards' but could be 'usefully' clarified in certain areas. ${ }^{123}$ In particular, the Committee endorsed the Commissioner's recommendation that:

the scope of the Code be amended to reflect that it does not seek to regulate Members' conduct in their purely private and personal lives, or their wider public lives unless that conduct significantly damages the reputation and integrity of the House of Commons as a whole or of its Members generally.

\footnotetext{
${ }^{121}$ The Code of Conduct Together with the Guide to the Rules Relating to the Conduct of Members (HC 2011-12, 1885) s 1.

122 Ibid s 8.

${ }^{123}$ Committee on Standards and Privileges, Review of the Code of Conduct (HC 2010-12, 19$) 4$.
} 
The Committee noted that in all but the 'most extreme circumstances' it is generally for political parties and the electorate to judge the behaviour of members of Parliament. ${ }^{124}$ However, in circumstances where a member's conduct in their private or wider public life is 'so extreme that it damages the reputation of the House' the conduct should fall within the Code. ${ }^{125}$ At the same time, the Committee was concerned to ensure that the House was not 'drawn into judging a Member's purely private and personal relationships'. ${ }^{126}$

Drawing on the Committee's recommendations, the scope of the Code is now limited to:

a Member's conduct which relates in any way to their membership of the House. The Code does not seek to regulate the conduct of Members in their purely private and personal lives or in the conduct of their wider public lives unless such conduct significantly damages the reputation and integrity of the House of Commons as a whole or of its Members generally. ${ }^{127}$

Under s 16 of the Code, members are required to "never undertake any action which would cause significant damage to the reputation and integrity of the House of Commons as a whole, or of its Members generally.' The Committee has expressed the opinion that this 'is a very high hurdle' which is only likely to be satisfied in 'extreme and extremely limited circumstances.' 128 The Code further reinforces the division between members' public and private lives in section 17: 'The Commissioner may not investigate a specific matter under paragraph 16 which relates only to the conduct of a Member in their private and personal lives.'

These sections attempt to reach a balance between the need to protect the integrity of Parliament and avoiding inappropriate interference in the personal and wider public lives of parliamentarians. This is obviously a difficult line to draw, and it is unclear what will constitute conduct that 'significantly damages the reputation and integrity' of the House. Further, section 17, which provides that the Commissioner may not investigate actions in a Member's private

\footnotetext{
${ }^{124}$ Ibid 5.

${ }^{125}$ Ibid 6

${ }^{126}$ Ibid.

${ }^{127}$ The Code of Conduct Together with the Guide to the Rules Relating to the Conduct of Members (n 121) s 2.

${ }^{128}$ Committee on Standards and Privileges, House of Commons, Procedural Note: Parliamentary Commissioner

for Standards $\quad-\quad$ Procedure for Inquiries $\quad$ (April 2012 ) 3 $<$ http://www.parliament.uk/documents/documents/Procedural_Note-April_2012.pdf $>$ accessed 22 September 2012.
} 
life that could cause significant damage to the reputation and integrity of the House, simultaneously recognises that personal conduct can damage the reputation and integrity of the House while also providing that established mechanisms cannot be used to manage such conduct. This leaves the Code in an 'unsatisfactory and unsettled position' where the House is either unable to act or is required to 'try to initiate some unprecedented procedure' ${ }^{129}$

The Code's implementation is monitored by the Parliamentary Commissioner for Standards, who is appointed by the House of Commons as an independent officer of the House. ${ }^{130}$ The Commissioner's role includes providing advice on the interpretation of the Code and 'questions of propriety', monitoring the operation of the Code and investigating the conduct of members. ${ }^{131}$ The Commissioner reports to the Committee on Standards, which oversees the Commissioner's work. ${ }^{132}$ The Commissioner may appoint an Investigatory Panel to assist in their investigations ${ }^{133}$ and provides an annual report to the House on the exercise of their functions. ${ }^{134}$

Infringements of the Code are investigated by the Commissioner who in turn reports their findings to the Committee. Following review of the Commissioner's report, the Committee reports its own conclusions and recommendations to the House. The House may impose a sanction on a member for breach of the Code 'where it considers it necessary'. ${ }^{135}$ The sanctions available are effectively limited to requiring a personal apology or imposing a period of suspension with loss of pay. ${ }^{136}$ While the House retains the power to expel a member, this has not been used since 1947 and the House has no power to institute a fine. ${ }^{137}$

Between April 2011 and April 2012, the Commissioner received 109 formal complaints or allegations against 93 Members and former Members. ${ }^{138}$ The majority of complaints (81) fell

\footnotetext{
${ }^{129}$ Parliamentary Commissioner for Standards (n 117) 8.

${ }^{130}$ Standing Orders of the House of Commons (The Stationery Office 2012) cl 150(1).

${ }^{131}$ Ibid cl 150(2).

132 Ibid cl 149(1)(b), 150(2)(e).

${ }^{133}$ Ibid cl 150(4).

${ }^{134}$ Ibid cl 150(10).

${ }^{135}$ The Code of Conduct Together with the Guide to the Rules Relating to the Conduct of Members (n 121) ss 19, 20.

136 Oonagh Gay, 'The Code of Conduct for Members - Recent Changes' (Standard Note No PC/05127, Parliamentary Library, House of Commons 2011) 3-4.

${ }^{137}$ Ibid. While the House of Commons expelled Peter Baker in 1954, this was at Baker's own instigation: see Allen (n 15) 216.

138 Parliamentary Commissioner for Standards (n 117) 16.
} 
outside the remit of the Commissioner, with only eight complaints ultimately being accepted for inquiry. ${ }^{139}$ Complaints beyond the Commissioner's remit include those relating to policy matters, members' views or opinions, members' handling of or decisions about individual cases, members' conduct in their private or personal lives, expenses (which are addressed by the Independent Parliamentary Standards Authority) or alleged breaches of the Code of Conduct for Ministers. ${ }^{140}$ Given this narrow remit, it is unsurprising that so few complaints fell within the Commissioner's purview. Of the complaints accepted for inquiry, 12 were resolved in 2011-12. All of these complaints related to the registration or declaration of financial interests or the use of parliamentary allowances, facilities and office costs. ${ }^{141}$

The Committee on Standards and Privileges is able to consider any matter relating to the conduct of members, including by addressing alleged breaches of the Code brought to the Committee's attention by the Commissioner. ${ }^{142}$ In March 2012, the House of Commons agreed to establish a new Committee on Standards with at least two and no more than three lay members. ${ }^{143}$ The new Committee on Standards will review the work of the Parliamentary Commissioner for Standards and consider reports from the Commissioner on breaches of the Code. ${ }^{144}$

\section{(b) House of Lords}

The House of Lords Code of Conduct has been in place since 2002. The purpose of the Code is to provide members with guidance on the standards expected of them in the discharge of their duties and to provide openness and accountability and to 'reinforce public confidence' in members performing their duties. ${ }^{145}$ The Code is explicitly limited to members' conduct in the discharge of their parliamentary duties - the Code does not extend to the 'performance of duties unrelated to parliamentary proceedings, or to [members'] private lives'. ${ }^{146}$

\footnotetext{
139 Ibid.

140 Ibid.

${ }^{141}$ Ibid 21.

142 Standing Orders of the House of Commons (n 130) cl 149(1)(c).

${ }^{143}$ Parliamentary Commissioner for Standards (n 117) 9.

144 Ibid.

145 Code of Conduct for Members of the House of Lords and Guide to the Code of Conduct (2nd edn, The Stationery Office 2011) s 3.

146 Ibid.
} 
Like the Code for the House of Commons, the Code in the House of Lords makes reference to the seven general principles of conduct, which are 'taken into consideration' when investigating a breach of the Code. ${ }^{147}$ However, unlike in the House of Commons, the rules of conduct in the Code are limited to registering and declaring 'relevant interests'. The Code is reviewed once each Parliament by the Sub-Committee on Lords' Conduct, a sub-committee of the Committee for Privileges and Conduct. ${ }^{148}$

Alleged breaches of the Code are investigated by the House of Lords Commissioner for Standards and reported to the Sub-Committee on Lords' Conduct. ${ }^{149}$ Having reviewed the Commissioner's findings, the Sub-Committee may recommend any appropriate disciplinary sanction to the Committee for Privileges and Conduct. ${ }^{150}$ The member concerned may appeal the Commissioner's findings or the recommended sanction to the Committee. ${ }^{151}$ The Committee reports its conclusions and recommendations to the House of Lords, which is responsible for making the final decision. ${ }^{152}$

The Commissioner is appointed by the House of Lords but is functionally independent in the exercise of their functions. ${ }^{153}$ The Commissioner received 12 complaints between June 2010 and 31 May 2011. Of these, eight complaints fell beyond the Commissioner's remit, ${ }^{154}$ which is limited to failures to register or declare relevant interests and breaching the rules on financial inducements, parliamentary influence, paid advocacy, the use of facilities and services and financial support. ${ }^{155}$

\section{Independent Standards Authority}

In 2009, the Independent Parliamentary Standards Authority (IPSA) was created by the Parliamentary Standards Act 2009 (UK) to independently oversee and regulate expenses for members of Parliament. IPSA is now also responsible for determining and paying members'

\footnotetext{
147 Ibid s 9.

148 Ibid s 24.

149 Ibid s 16.

${ }^{150}$ Ibid s 17.

${ }^{151}$ Ibid.

152 Ibid.

${ }^{153}$ House of Lords Commissioner for Standards, Annual Report 2010-2011 (House of Lords 2011) 2, 4.

154 Ibid 6.

155 Ibid.
} 
expenses, salaries and pensions. IPSA is independent of Parliament and the government. However, IPSA does not regulate the House of Lords in most respects. ${ }^{156}$

An independent Compliance Officer role has also been created under the auspices of IPSA with responsibility for investigating complaints about the misuse of parliamentary allowances and expenses. ${ }^{157}$ The Officer is able to require the repayment of funds and issue penalty notices and may refer a matter to the Parliamentary Standards Commissioner where it appears that the Code may have been breached. ${ }^{158}$ During 2011-12, the Compliance Officer handled 76 cases. Of these, 32 were closed at the assessment stage, 21 at preliminary investigation, 22 at substantive investigation, and one was carried forward to $2012-13 .{ }^{159}$ Of the 22 cases resolved following a substantive investigation, 21 related to reimbursement for website expenses. All the investigated cases were resolved by either the member repaying the reimbursement or rectifying the issue.

In addition to IPSA, the Committee on Standards in Public Life acts as an independent advisory body to the government. The Committee monitors and reports on issues relating to standards in public life, including parliamentary standards.

\section{B Republic of Ireland}

\section{Code of Conduct and Internal Regulation}

\section{(a) Dáil Éireann (Lower House)}

The Code Of Conduct For Members Of Dáil Éireann Other Than Office Holders was adopted by Dail Eireann in 2002. The purpose of the Code is to: 'assist Members in the discharge of their obligations ... without, however, trespassing into areas where Members more properly submit themselves to the judgement of their electors rather than the jurisdiction of this House.'

As noted in the Preamble to the Code:

\footnotetext{
156 Parliamentary Standards Act 2009 (UK) c 13, s 2.

${ }^{157}$ Constitutional Reform and Governance Act 2010 (UK) c 25, ss 26, 33.

158 Ibid s 34, sch 4. See also Gay, 'The Code of Conduct for Members' (n 136) 4.

${ }^{159}$ See also Independent Parliamentary Standards Authority, Annual Report and Accounts 2010-11 (HC 201112, 1249) 60 .
} 
Members are in the unique position of being responsible to the electorate which is the final arbiter of their conduct and has the right to dismiss them from office at regular elections. Accordingly, and as a matter of principle, individual Members are not answerable to their colleagues for their behaviour, except where it is alleged to breach the obligations to answer to them which have been placed on Members by law, by Standing Orders or by Codes of Conduct established by the House.

Clause 2 of the Code states:

Members must conduct themselves in accordance with the provisions and spirit of the Code of Conduct and ensure that their conduct does not bring the integrity of their office or the Dáil into serious disrepute.

Beyond this clause, the majority of provisions are directed to preventing and managing conflicts of interest.

The Code does not have any direct means of enforcement. However, members are required to have regard to and be guided by the Code in the performance of their functions. ${ }^{160}$ Further, a court or tribunal or the Standards in Public Office Commission (discussed below) may take a Code into account in determining a question. ${ }^{161}$

Members' conduct more broadly may be considered and reported on by a parliamentary Committee on Procedures and Privileges. The Committee's role encompasses considering matters of procedure, recommending additions or amendments to parliamentary Standing Orders and considering and reporting on matters of privilege when requested to do so. In the past, the Committee has considered issues such as whether members should be able to call premium rate telephone numbers from parliamentary phone lines (following a controversy in which $€ 2,600$ was charged to the Parliament for calls made in support of a member on a

${ }^{160}$ Standards in Public Office Act 2001 (Republic of Ireland) s 10(7).

${ }^{161}$ Ibid s 10(8). 
celebrity television show); ${ }^{162}$ the introduction of a parliamentary dress code; a 'verbal assault' by one member against another; ${ }^{163}$ and standards of behaviour in parliamentary debate. ${ }^{164}$

The Committee on Members' Interests of Dáil Éireann is also empowered to investigate public complaints regarding members' failures to register or declare material interests in accordance with a statutory scheme. ${ }^{165}$ The Committee submits its reports to Parliament ${ }^{166}$ and may put a parliamentary motion asking the House to acknowledge its report, censure or suspend a member for up to 30 sitting days or until they have fulfilled their disclosure requirements. ${ }^{167}$ In 2000, these provisions resulted in the suspension of Deputy Denis Foley for 14 sitting days following a report by the Committee. ${ }^{168}$

Despite the presence of a code of conduct and two parliamentary committees capable of monitoring members' conduct, there is still the potential for gaps in accountability to occur. In 2012, concerns were raised that a company owned by a member of Parliament had submitted false Value-Added Tax declarations. The Committee on Procedures and Privileges was thought to 'have no function' in relation to investigating whether a member's tax affairs were having a detrimental impact on the reputation of Parliament, instead referring the matter to the Committee on Members' Interests. ${ }^{169}$ After a preliminary consideration of the matter, the Committee on Members' Interests also concluded that it had no jurisdiction to investigate as it appeared that the declarations had occurred before the member entered Parliament. ${ }^{170}$

\footnotetext{
${ }^{162}$ Houses of the Oireachtas, 'Committee on Procedure and Privileges of Dáil Éireann - Dáil Committee Takes Action on Telephones' (Press $\quad$ Release, 7 July 2011 ) $<$ http://www.oireachtas.ie/parliament/mediazone/pressreleases/2011/name-2322-en.html> accessed 22 September 2012

163 Shaun Connolly, 'Mingin' Jeans Banned in Dáil Dress Code' Irish Examiner (Cork, 8 August 2012) $<$ http://www.irishexaminer.com/ireland/mingin-jeans-banned-in-dail-dress-code-203390.html> accessed 22 September 2012.

${ }^{164}$ Dáil Éireann Committee on Procedure and Privileges, Parliament of the Republic of Ireland, Report of the Committee on Procedure and Privileges on Parliamentary Standards (2010); Houses of the Oireachtas, 'Statement by Dáil Committee on Procedure and Privileges re Parliamentary Standards' (Press Release, 15 December 2009) <http://www.oireachtas.ie/parliament/mediazone/pressreleases/2009/name-1385-en.html> accessed 22 September 2012.

165 Ethics in Public Office Act 1995 (Republic of Ireland) s 8.

166 Ibid s 10.

167 Ibid s 28.

${ }^{168}$ Republic of Ireland, Parliamentary Debates, Dáil Éireann, 23 May 2000, vol 519, col 995.

${ }^{169}$ Houses of the Oireachtas, 'Statement from Seán Barrett, TD, Ceann Comhairle and Chairman of the Dáil Committee on Procedure and Privileges' (Press Release, 8 June 2012) $<$ http://www.oireachtas.ie/parliament/mediazone/pressreleases/name-8243-en.html $>$ accessed 22 September 2012.

${ }^{170}$ Houses of the Oireachtas, 'Committee on Members' Interests of Dáil Éireann Publishes Report into Matters Arising from the Under-Declaration of VAT by M\&J Wallace Ltd' (Press Release, 11 July 2012)
} 
The Code Of Conduct For Members Of Seanad Éireann Other Than Office Holders was adopted by Seanad Éireann in 2002. The Code is intended to 'guide Members in the discharge of their obligations'. Clause 2 of the Code states that:

Members must conduct themselves in accordance with the provisions and spirit of the Code of Conduct and ensure that their conduct does not bring the integrity of their office or the Seanad into disrepute.

Again, like the Code for the Dáil Éireann, the majority of provisions in the Code are directed to preventing and managing conflicts of interest.

Members' conduct is also monitored by the Committee on Procedure and Privileges of Seanad Éireann, which may consider matters relating to standing orders and members' privileges, and the Committee on Members' Interests of Seanad Éireann, which may receive and investigate complaints regarding members' failure to register or declare material interests. ${ }^{171}$ Like the Dáil Éireann Committees, the Committees of Seanad Éireann report to Parliament. ${ }^{172}$ Further, the Committee on Members' Interests may put a parliamentary motion that the House acknowledges its report, censures or suspends a member for up to 30 sitting days or until they have fulfilled legislative disclosure requirements. ${ }^{173}$

\footnotetext{
$<\mathrm{http} / /$ www.oireachtas.ie/parliament/mediazone/pressreleases/name-8873-en.html > accessed 22 September 2012; Committee on Members' Interests of Dáil Eireann, Parliament of the Republic of Ireland, Consideration of Matters Arising from the Under-Declaration of Value Added Tax by M\&J Wallace Ltd: Report of the Committee (2012) 7.

${ }^{171}$ Ethics in Public Office Act 1995 (Republic of Ireland) ss 8, 9.

172 Ibid s 10.

${ }^{173}$ Ibid s 28.
} 
The Committee on Members' Interests has conducted investigations into members' expense and allowance claims ${ }^{174}$ (resulting in a member being censured and suspended for 20 sitting days without pay) ${ }^{175}$ and conducted other investigations into complaints against members. ${ }^{176}$

\section{Independent Standards Authority}

The Standards in Public Office Commission was established under the Standards in Public Office Act 2001 to replace the Public Offices Commission established under the Ethics in Public Office Act 1995. ${ }^{177}$ The Commission is responsible for administering regimes relating to the disclosure of interests and tax clearances and has wide investigative powers in relation to complaints about persons in public life. The Commission may also provide advice relating to the application of codes of conduct. ${ }^{178}$

Members of the public are unable to make a complaint to the Commission about a member of Parliament. However, public complaints may be made to the Clerk of each House of Parliament, who refers matters to the Committee on Members' Interests for consideration. The Committee may then choose to refer the matter to the Commission for investigation. ${ }^{179}$

Complaints may be referred to the Commission if a member has allegedly done an act that is:

inconsistent with the proper performance ... of the functions of the office or position ... or with the maintenance of confidence in such performance by the general public, and the matter is one of significant public importance. ${ }^{180}$

\footnotetext{
${ }^{174}$ Houses of the Oireachtas, 'Statement by Select Committee on Members' Interests of Seanad Éireann' (Press Release, 3 June 2010) <http://www.oireachtas.ie/parliament/mediazone/pressreleases/2010/name-1824-en.html> accessed 22 September 2012.

${ }^{175}$ Committee on Members' Interests of Seanad Éireann, Parliament of the Republic of Ireland, Report of the Results of an Investigation into Complaints Concerning Senator Ivor Callely (2010) 10. However, note that the suspension was later overturned by the High Court, with the member awarded $€ 17,000$ for loss of earnings: see Callely v Moylan [2011] IEHC 2 (14 January 2011); 'Ivor Callely awarded $€ 17,000$ by High Court' RTE News (Dublin, 31 January 2011) <http://www.rte.ie/news/2011/0131/callelyi.html> accessed 22 September 2012.

${ }^{176}$ Houses of the Oireachtas, 'Statement by Select Committee on Members' Interests of Seanad Éireann' (Press Release, 9 August 2010) <http://www.oireachtas.ie/parliament/mediazone/pressreleases/2010/name-1911en.html $>$ accessed 22 September 2012.

${ }^{177}$ For a description and explanation of this change see Public Offices Commission, Republic of Ireland, Annual Report of the Public Offices Commission 2001 (2002) 5-6.

${ }^{178}$ Standards in Public Office Act 2001 (Republic of Ireland) s 10(12).

${ }^{179}$ Ibid s 7(1A).

${ }^{180}$ Ibid s 4(1).
} 
Following the Commission's investigation, it is up to Parliament to determine what action, if any, should be taken as a result of the Commission's report. ${ }^{181}$

The Commission completed its first formal investigation in December 2001 in relation to Deputy Ned O'Keeffe. The investigation found that O'Keeffe had negligently failed to declare a material interest before participating in a parliamentary debate and had failed to disclose interests of family members. ${ }^{182}$ O'Keeffe was suspended from Parliament with pay for 10 sitting days. ${ }^{183}$

Concerns have been raised that the Commission's investigations are overly time-consuming and onerous, and that 'tit for tat' allegations will emerge, with members making public accusations against other members. ${ }^{184}$ Further, the Commission's jurisdiction is limited to investigating sitting members of Parliament. As a result, the Commission may be forced to abandon investigations regarding parliamentary conduct when members leave Parliament. This occurred in an investigation into complaints that Senator Ivor Callely had made inaccurate claims for mobile phones under a direct purchase scheme, ${ }^{185}$ despite the Commission reaching a preliminary conclusion that the Senator might have committed an offence relating to the performance of his functions as a member. ${ }^{186}$

\section{Lessons from Comparative Jurisdictions}

The above examination of mechanisms to manage parliamentary behaviour in the UK and the Republic of Ireland reveals a number of telling lessons. First, where Codes are in place, the majority of provisions are concerned with managing conflicts of interest and the use of parliamentary resources and allowances. This is perhaps unsurprising, especially given the prevalence of recent allowance scandals in the UK. However, the result of this focus is that other forms of misconduct receive limited attention and guidance in the Codes. As a result, the

\footnotetext{
${ }^{181}$ Ethics in Public Office Act 1995 (Republic of Ireland) s 28.

182 Public Offices Commission (n 177) 9-11.

${ }^{183}$ Republic of Ireland, Parliamentary Debates, Dáil Éireann, 7 March 2002, vol 550, no 2, 22.

184 Oonagh Gay, 'The Regulation of Parliamentary Standards - A Comparative Perspective' (Report, The Constitution Unit, University College London, May 2002) 63.

185 Standards in Public Office Commission, 'Former Senator Ivor Callely' (Press Release, 28 April 2011) $<$ http://www.sipo.gov.ie/en/PressReleases/Name,13923,en.htm> accessed 22 September 2012.

${ }^{186}$ However, a report on the Commission's preliminary conclusions was furnished to the Director of Public Prosecutions: ibid.
} 
Codes often fail to address areas of misconduct that are 'corrosive of public trust' in any detail. $^{187}$

Similarly, where independent standards authorities are in place, their role is generally limited to the management and investigation of financial issues, rather than investigating members' conduct more broadly. This likely reflects the focus on conflicts of interests and financial matters in the relevant Codes. However, again, the end result is that there are few processes for managing other forms of misconduct.

These comparative perspectives also reveal operational challenges in managing members' misconduct. While investigations of misconduct can be conducted by independent Commissioners in both jurisdictions, it is ultimately Parliament's responsibility to determine what sanctions, if any, should be applied. This has the potential to lead to accusations of parliamentarians 'protecting their own'. ${ }^{188}$ At present there is only limited evidence of how these comparative mechanisms operate in practice. As a result, any application of these ideas to the Australian federal context should also be justified on first principles.

\section{THE AUSTRALIAN STATES AND TERRITORIES}

It is also useful to consider how the conduct of members of Parliament is managed in the Australian States and Territories. Table 3 below illustrates the mechanisms present in these jurisdictions.

Table 3: Regulation of Behaviour for Members of Parliament in the Australian States and Territories

\begin{tabular}{|l|c|c|c|c|}
\hline Jurisdiction & $\begin{array}{c}\text { Parliamentary } \\
\text { Committee }\end{array}$ & $\begin{array}{c}\text { Code of } \\
\text { Conduct }\end{array}$ & $\begin{array}{c}\text { Ethics } \\
\text { Adviser }\end{array}$ & $\begin{array}{c}\text { Independent } \\
\text { Standards } \\
\end{array}$ \\
& & & & Authority \\
\hline
\end{tabular}

\footnotetext{
187 Andrew Brien, 'A Code of Conduct for Parliamentarians?' (Research Paper No 2, Parliamentary Library, Parliament of Australia 1998).

188 Ibid.
} 


\begin{tabular}{|c|c|c|c|c|}
\hline $\begin{array}{l}\text { New South } \\
\text { Wales }\end{array}$ & $\begin{array}{l}\text { Legislative Council } \\
\text { Privileges } \\
\text { Committee; } \\
\text { Legislative } \\
\text { Assembly } \\
\text { Parliamentary } \\
\text { Privilege and Ethics } \\
\text { Committee }\end{array}$ & $\begin{array}{l}\text { Code of } \\
\text { Conduct, } \\
\text { Members of } \\
\text { Parliament, } \\
\text { New South } \\
\text { Wales }\end{array}$ & $\begin{array}{l}\text { Parliamentary } \\
\text { Ethics } \\
\text { Adviser }\end{array}$ & $x^{189}$ \\
\hline Victoria & $\begin{array}{l}\text { Legislative } \\
\text { Assembly } \\
\text { Privileges } \\
\text { Committee; } \\
\text { Legislative Council } \\
\text { Privileges } \\
\text { Committee }\end{array}$ & $\begin{array}{l}\text { Members of } \\
\text { Parliament } \\
\text { (Register of } \\
\text { Interests) Act } \\
1978 \text { (Vic) }\end{array}$ & $\mathbf{x}$ & $\mathbf{x}$ \\
\hline Queensland & $\begin{array}{l}\text { Committee of the } \\
\text { Legislative } \\
\text { Assembly } \\
\text { Ethics Committee }\end{array}$ & $\begin{array}{l}\text { Code of } \\
\text { Ethical } \\
\text { Standards } \\
\text { Legislative } \\
\text { Assembly of } \\
\text { Queensland }\end{array}$ & $\begin{array}{l}\text { Integrity } \\
\text { Commissioner }\end{array}$ & $\mathbf{x}$ \\
\hline South Australia & $\begin{array}{l}\text { Ad hoc Privileges } \\
\text { Committees }\end{array}$ & $\mathbf{x}$ & $\mathbf{x}$ & $\mathbf{x}$ \\
\hline Tasmania & $\begin{array}{l}\text { Joint Standing } \\
\text { Committee } \\
\text { Integrity }\end{array}$ & $\begin{array}{l}\text { Code of } \\
\text { ethical conduct } \\
\text { for Members } \\
\text { of the House } \\
\text { of Assembly }\end{array}$ & $\begin{array}{l}\text { Parliamentary } \\
\text { Standards } \\
\text { Commissioner }\end{array}$ & $\begin{array}{l}\text { Integrity } \\
\text { Commission }\end{array}$ \\
\hline $\begin{array}{l}\text { Western } \\
\text { Australia }\end{array}$ & $\begin{array}{l}\text { Legislative Council } \\
\text { Procedure and }\end{array}$ & $\begin{array}{l}\text { Code of } \\
\text { Conduct for } \\
\text { Members of }\end{array}$ & $\mathbf{x}$ & $\mathbf{x}$ \\
\hline
\end{tabular}

${ }^{189}$ The Legislative Council Privileges Committee has recommended that consideration be given to establishing a Parliamentary Integrity Commissioner: Legislative Council Privileges Committee, Parliament of New South Wales, Final Report: Review of the Members' Code of Conduct (2010). 


\begin{tabular}{|c|c|c|c|c|}
\hline & $\begin{array}{l}\text { Privileges } \\
\text { Committee; } \\
\text { Legislative } \\
\text { Assembly } \\
\text { Procedure and } \\
\text { Privileges } \\
\text { Committee }\end{array}$ & $\begin{array}{l}\text { the Western } \\
\text { Australian } \\
\text { Legislative } \\
\text { Assembly }\end{array}$ & & \\
\hline $\begin{array}{l}\text { Northern } \\
\text { Territory }\end{array}$ & $\begin{array}{l}\text { Privileges } \\
\text { Committee }\end{array}$ & $\begin{array}{l}\text { Legislative } \\
\text { Assembly } \\
\text { (Members' } \\
\text { Code of } \\
\text { Conduct and } \\
\text { Ethical } \\
\text { Standards) Act } \\
2008 \text { (NT) }\end{array}$ & $\overline{\mathbf{X}}$ & $\overline{\mathbf{x}}$ \\
\hline $\begin{array}{l}\text { Australian } \\
\text { Capital } \\
\text { Territory }\end{array}$ & $\begin{array}{l}\text { Ad hoc Privileges } \\
\text { Committees }\end{array}$ & $\begin{array}{l}\text { Code of } \\
\text { conduct for all } \\
\text { Members of } \\
\text { the Legislative } \\
\text { Assembly of } \\
\text { the Australian } \\
\text { Capital } \\
\text { Territory }\end{array}$ & $\begin{array}{l}\text { Ethics and } \\
\text { Integrity } \\
\text { Adviser }\end{array}$ & $\mathbf{x}$ \\
\hline
\end{tabular}

Table 3 demonstrates that most of the Australian States and Territories have parliamentary committees, often a Privileges Committee or similar, and a code of conduct to assist with managing the conduct of parliamentarians. However, ethics advisers and independent standards authorities are less apparent.

Like those in the UK and Republic of Ireland, the majority of codes of conduct in the States and Territories are intended to address conflicts of interest and the misuse of resources, with minimal consideration of broader misconduct. The key exception is the Queensland Code, 
which includes a Statement of Fundamental Principles to 'assist members to better understand their representative role and responsibilities'. The first of these principles states:

\section{Integrity of the Parliament}

The public's confidence in the institution of Parliament is essential. Members are to strive at all times to conduct themselves in a manner which will tend to maintain and strengthen the public's trust and confidence in the integrity of Parliament and avoid any action which may diminish its standing, authority or dignity. ${ }^{190}$

However, the fact that these principles are separate from a member's 'obligations' under the Code appears to imply that the principles are non-enforceable, similar to the situation in the UK. Similarly, the Tasmanian Code lists nine general declarations, including one related to personal conduct. Again, there is no specified standard of behaviour or means of enforcement.

While attempts have been made in some jurisdictions to extend codes to encompass other forms of misconduct, this has met with limited success. In 2009, the Victorian Law Reform Committee tabled a report recommending that that State's Code of Conduct be replaced by a broader code that included a statement of values for members of Parliament. ${ }^{191}$ In particular, the Committee recommended that the following clause be included:

\section{Personal conduct}

Members of parliament must ensure their conduct as members does not bring discredit upon the Parliament.

Members of parliament must act with honesty and integrity in all official dealings and must not deliberately mislead the Parliament or the public about any matter relating to the performance of their public duties.

Members of parliament must be fair, objective and courteous in their dealings with the community and, without detracting from the importance of robust public debate in a democracy, their colleagues.

\footnotetext{
${ }^{190}$ Legislative Assembly of Queensland, Code of Ethical Standards (2004) 3.

${ }^{191}$ Law Reform Committee, Parliament of Victoria, Review of the Members of Parliament (Register of Interests) Act 1978 (1999) 42-44.
} 
However, legislation to introduce these changes lapsed at the end of the 56th Victorian Parliament in 2010. ${ }^{192}$ Similarly, the Members of Parliament (Serious Misconduct) Amendment Bill 2011 (Vic), which proposed to establish a new offence for serious misconduct by a member of Parliament, punishable by up to 5 years imprisonment, is languishing in the Legislative Council, having not proceeded beyond the second reading.

In all of the States and Territories except Tasmania, breach of a code of conduct is referred to a parliamentary committee for consideration. In contrast, in Tasmania the Integrity Commission is tasked with receiving and investigating complaints relating to matters of misconduct, as well as educating public officers (including members of Parliament) about integrity in public administration and providing advice about the implementation of standards of conduct. ${ }^{193}$

In limited circumstances, breaches of a code of conduct in NSW may be referred to an independent standards authority: 'substantial breaches' of the parliamentary Code are regarded as corrupt conduct, and therefore fall within the purview of the Independent Commission Against Corruption. ${ }^{194}$ If this body determines that there has been a substantial breach of the code of conduct, the finding will be reported to the relevant House of Parliament, which will determine what disciplinary action, if any, is appropriate.

Finally, Parliaments in Tasmania, NSW, Queensland and the ACT have an ethics adviser to provide advice to members on conduct, propriety and ethics and the implementation of codes of conduct. ${ }^{195}$ By issuing non-binding opinions and advice to members, it is hoped that the role will assist with resolving members' ethical issues and problems. ${ }^{196}$

\section{AN AUSTRALIAN MODEL OF EXTENDED ACCOUNTABILITY}

As noted in Part IV above, the Australian federal system for managing parliamentarians' misconduct has major gaps, including the absence of effective mechanisms for: securing short-

\footnotetext{
192 Members of Parliament (Standards) Bill 2010 (Vic).

193 Integrity Commission Act 2009 (Tas) s 8(1).

${ }^{194}$ Independent Commission Against Corruption Act 1988 (NSW) s 9(1)(d).

195 See, for example, Integrity Commission Act 2009 (Tas) s 28(1).

${ }^{196}$ Edward Dickson, Submission No MP/23 to Law Reform Committee, Parliament of New South Wales, Review of the Members of Parliament (Register of Interests) Act 1978, 16 June 2009, 1.
} 
term accountability for misconduct by members of Parliament; addressing many forms of personal misconduct that fall short of a criminal offence; and addressing non-criminal conduct that occurred prior to members entering Parliament, but which has the potential to undermine public confidence in Parliament. It is therefore necessary to consider whether comparative ideas may help to address these gaps by introducing additional internal or external regulation of parliamentary behaviour.

\section{A Internal Regulation}

The Australian federal Parliament is heavily reliant on non-legal, ad-hoc political repercussions to manage misconduct by its members. While the work of Parliament will, by its nature, always have a political dimension and be non-legal, it may be possible to adopt a more systematic approach to managing misconduct. Taking into account the caveats and concerns expressed in Part IV, it is therefore worth considering whether other forms of internal regulation would be beneficial accompaniments to existing political processes.

In Australia there have been repeated calls to introduce a Code of Conduct at the federal level, ${ }^{197}$ leading to a number of draft Codes being developed. ${ }^{198}$ Indeed, development of a Code of Conduct was a key element in the agreements between the Australian Labor Party, independents and the Greens upon forming government in $2010 .{ }^{199}$ Introducing a Code of Conduct in the Australian federal Parliament could provide a useful non-legal reminder of proper parliamentary behaviour that could support members in performing their roles by providing guidance in the event of ethical and other dilemmas. ${ }^{200}$ Further, the implementation

\footnotetext{
${ }^{197}$ See, for example, Joint Committee on Pecuniary Interests of Members of Parliament, Parliament of Australia, Report on Declaration of Interests (1975); House of Representatives Standing Committee of Privileges and Members' Interests, Report on the Issue of the Exchange between the Member for Robertson and the Member for Indi (n 74) 10; Commonwealth, Parliamentary Debates, House of Representatives, 4 December 2008, 12726 (Harry Jenkins, Speaker).

198 See, for example, Deirdre McKeown, 'Codes of Conduct in Australian and Some Overseas Parliaments' (Parliamentary Library, Parliament of Australia 2003); Brien (n 187).

${ }^{199}$ See Australian Labor Party and the Independent Members Rob Oakeshott and Tony Windsor, 'Agreement' (Minister for Regional Australia, Regional Development and Local Government, 7 September 2010) 9 $<$ http://www.minister.regional.gov.au/files/Regional_Agreement.pdf> accessed 22 September 2012; Australian Labor Party and the Independent Member Andrew Wilkie, 'Agreement' (Australian Labor Party, 2 September 2010) $3<$ http://www.alp.org.au/federal-government/government-agreements/> accessed 22 September 2012; Australian Labor Party and the Australian Greens, 'Agreement' (Australian Labor Party, 1 September 2010) 3 $<$ http://www.alp.org.au/getattachment/255f5397-f9da-41c8-97c3-72287595d2eb/government-agreements/> accessed 22 September 2012.

${ }^{200}$ Carney (n 38) 260; House of Representatives Standing Committee of Privileges and Members' Interests, Parliament of Australia, Draft Code of Conduct for Members of Parliament-Discussion Paper (2011) 21.
} 
of a Code of Conduct is regarded as a 'better practice' to be adopted by all democratic parliaments. $^{201}$ However, it has been difficult to achieve any consensus regarding the appropriate standards to be included in a Code. ${ }^{202}$ The most recent draft Code was proposed in December 2011 by the House of Representatives Standing Committee of Privileges and Members' Interests. ${ }^{203}$ The Committee was strongly influenced by the UK experience, adopting a Code with a number of similar features to that in the UK House of Commons.

Drawing on comparative experiences, the Committee recommended adoption of a Code of Conduct by resolution of each house of Parliament, as it was felt this would limit the possibility of judicial intervention in the enforcement of the Code and allow Parliament to retain 'control over its own affairs'. ${ }^{204}$ The Committee also felt this arrangement would ensure that the Code was easily amendable (and thus responsive to change) and would encourage parliamentary ownership of the Code. ${ }^{205}$ On balance, adopting a Code as part of the Standing Orders of each house is likely to be the most appropriate means of introducing a Code of Conduct in the Australian federal context.

Under its Terms of Reference, the Committee was required to consult with the Committee of Senators' Interests with a view to ultimately developing and implementing a uniform Code for both houses of Parliament. ${ }^{206}$ While it is likely to prove challenging to reach agreement on the terms of a uniform Code, ${ }^{207}$ this would be the most efficient means of adopting a Code, as it would allow for the same bodies to implement, monitor and assist with enforcing the Code. Further, it would ensure that all members of federal Parliament are held to the same standards of conduct, reducing public confusion and avoiding inconsistency. If a uniform Code is adopted, it should be overseen by a joint parliamentary committee to ensure processes and standards are applied uniformly across both houses.

\footnotetext{
${ }^{201}$ House of Representatives Standing Committee of Privileges and Members' Interests, Draft Code of Conduct for Members of Parliament (n 200) 16.

202 Carney (n 38) 255.

${ }^{203}$ However, note that the Senate Standing Committee of Senators' Interests has not endorsed the Code developed by the House of Representatives Standing Committee: Senate Standing Committee of Senators' Interests, Parliament of Australia, Code of Conduct Inquiry (2012) 12.

${ }^{204}$ House of Representatives Standing Committee of Privileges and Members' Interests, Draft Code of Conduct for Members of Parliament (n 200) 34-5.

${ }^{205}$ Ibid.

${ }^{206}$ Ibid 4.

${ }^{207}$ See $\mathrm{n} 203$ above.
} 
The Committee's draft Code is stated to apply to: 'Members in all aspects of their public life. It does not seek to regulate what Members do in their purely private and personal lives.' ${ }^{208}$ However, at the same time, the draft Code contains the following principle on personal conduct, which closely resembles the first principle in the Queensland Code:

Members must ensure that their personal conduct is consistent with the dignity of the Parliament. They should act at all times in a manner which will tend to maintain and strengthen the public's trust and confidence in the integrity of the Parliament and its Members. $^{209}$

These two provisions make it entirely unclear whether the Code is intended to encompass personal misconduct that falls short of a criminal offence but has the potential to undermine public confidence in Parliament. However, this disparity is unlikely to make any practical difference, as the draft federal Code is limited to key principles and values intended to guide members' conduct. ${ }^{210}$ Unlike the UK House of Commons Code and Codes in many Australian States and Territories, these principles and values are not supplemented by any enforceable rules. As a result, the Code is unlikely to provide any meaningful or enforceable mechanism for addressing existing gaps in accountability.

Despite the Code having no enforceable rules, the Committee has proposed the establishment of a Parliamentary Integrity Commissioner responsible for receiving and investigating complaints about breaches of the Code, providing advice regarding the Code, periodically reviewing the Code and educating members about the Code's provisions. ${ }^{211}$ While the role of the Commissioner closely resembles that of the Tasmanian Integrity Commission, under the Standing Committee's draft Code the Commissioner would be appointed by the house ${ }^{212}$ under its standing orders and would be overseen by the Committee of Privileges and Members' Interests, ${ }^{213}$ rather than being an independent body.

\footnotetext{
${ }^{208}$ House of Representatives Standing Committee of Privileges and Members' Interests, Draft Code of Conduct for Members of Parliament (n 200) 75.

209 Ibid 77.

${ }^{210}$ Ibid 32.

${ }^{211}$ Ibid 43-44.

212 Ibid 44.

${ }^{213}$ Ibid 52-53.
} 
While the Committee has concluded that an independent and rigorous process for complaints is essential for a Code to have credibility, ${ }^{214}$ it is difficult to envisage how the Commissioner will investigate breaches of aspirational statements of conduct. ${ }^{215}$ While the Code will also cross-reference other rules and guidelines that relate to the parliamentary role and behaviour (such as standing orders and the Australian Constitution), ${ }^{216}$ as noted above these have significant gaps.

The limited scope of the draft Code is also evident in the Commissioner's remit. While the Commissioner would be able to receive complaints from any person regarding members' conduct, like in the UK the Commissioner's investigatory remit has been confined to exclude: policy matters; a Member's views or opinions; the handling of individual cases; the funding of political parties; the conduct of members in a ministerial capacity; and the purely private or personal lives of members. ${ }^{217}$ This is likely to exclude many matters of public concern from the Commissioner's role.

To adequately address existing accountability gaps, a more detailed, internally consistent and prescriptive Code will need to be developed. For the Code to be credible, it must be more than aspirational. ${ }^{218}$ It should contain clear guidelines and prescriptions. ${ }^{219}$ The Code must also deal effectively with actions (including personal conduct) that may bring or be thought to bring Parliament into disrepute. ${ }^{220}$ To achieve this, the scope of the Code could be extended to conduct that 'significantly damages the public's trust and confidence in the integrity of the Parliament or its Members' or has the potential to do so. It would also be necessary to provide clarification of what conduct may cause or have the potential to cause such 'significant damage', including where that conduct occurs before entering Parliament. To this end, guidelines should be produced to accompany and assist with interpretation of the Code. By directing and limiting the Code to conduct that may bring or be thought to bring Parliament into disrepute, the Code would adequately balance members' parliamentary duties with their personal privacy.

\footnotetext{
${ }^{214}$ Ibid 43.

215 See, for example, Senate Standing Committee of Senators' Interests, Code of Conduct Inquiry (n 203 ) 13.

${ }^{216}$ House of Representatives Standing Committee of Privileges and Members' Interests, Draft Code of Conduct for Members of Parliament (n 200) 33.

${ }^{217}$ Ibid 47.

218 Brien (n 187).

219 Ibid.

${ }^{220}$ Ibid.
} 
Unlike the Tasmanian model, the draft Code proposes that the Commissioner be the sole parliamentary adviser on ethical standards, rather than providing for an ethics adviser who is separate to the investigative function. As a result, the proposed Commissioner would only be able to give advice 'subject to such advice not creating a potential conflict with any possible investigations'. ${ }^{221}$ This is likely to leave members without advice in many complicated ethical situations, which is clearly not an ideal outcome. Instead, it would be desirable to establish a parliamentary ethics adviser position, to provide advice on the implementation of the Code and ethical matters generally, without the potential for conflicts of interest with later investigations.

Under the draft Code, the House would retain responsibility for imposing any sanction it deemed necessary in response to the Commissioner's investigations. ${ }^{222}$ While this model adopts key features of the UK system, it also retains the fundamental flaw that the Committee may reject the Commissioner's findings on partisan grounds. ${ }^{223}$ To address this issue, Brien proposes that the Committee be given the power to only reject a report on procedural grounds or if salient evidence has not been properly considered. ${ }^{224}$ If a report were rejected, it would be referred back to the Commissioner to be rectified. This process could be made even more effective by imposing time restraints for dealing with the Commissioner's reports. ${ }^{225}$ If these proposals were followed, the Committee would only be able to reject the Commissioner's recommendations on procedural grounds. In the event there was not a procedural problem, the Commissioner's recommendation would automatically proceed to the floor of Parliament for a vote, with Parliament able to either endorse the recommendations of the Commissioner or follow some other course. There is merit in this model: while Parliament retains final control over sanctions for its members, and may reject the Commissioner's report on partisan grounds, doing so is likely to come at significant political cost.

It is also necessary to consider what sanctions might be appropriate to enable Parliament to effectively enforce such a Code. The Australian federal Parliament already has the power under parliamentary privilege to admonish, suspend or imprison its members for misbehaviour and

\footnotetext{
${ }^{221}$ House of Representatives Standing Committee of Privileges and Members' Interests, Draft Code of Conduct for Members of Parliament (n 200) 43.

222 Ibid 57.

${ }^{223}$ Brien (n 187).

224 Ibid.

225 Ibid.
} 
may impose fines for offences 'against the House'. ${ }^{226}$ However, the narrow definition of offences against the House excludes many forms of misconduct.

To be effective, sanctions should provide Parliament with meaningful ways to enforce the Code, and provide a degree of deterrence to discourage members from breaching the Code. However, sanctions should not interfere with court processes and should be proportionate to the harm caused or posed by the misconduct. In this context, it is inappropriate for Parliament to be able to imprison its members for misconduct, particularly where that misconduct does not constitute a criminal offence or the matter more properly falls within the purview of the courts. However, it may be appropriate for Parliament to admonish or suspend its members for a not unreasonable period of time. However, as the Thomson and Slipper cases illustrate, the government may be unwilling to suspend one of its own members for misbehaviour, particularly in a hung Parliament. As a result, political circumstances may inescapably limit the sanctions available to allow Parliament to respond to breaches of a Code. The same considerations do not apply to the imposition of a fine: a fine will not affect the balance of political power, and may still fulfill a deterrent function. As a consequence, it may be desirable to amend the Parliamentary Privileges Act 1987 (Cth) s 7(5) to enable Parliament to impose fines on its members for breaches of the Code.

In cases of misconduct, a non-enforceable Code could provide a yardstick for political and media debate as to whether particular behaviour is acceptable. However, without an ability to impose some form of repercussion for misbehaviour, a Code is unlikely to address existing accountability gaps or significantly improve public perceptions of Parliament. The model proposed above addresses these issues by providing more effective means to investigate and enforce breaches of a Code, including in relation to personal conduct that has the potential to undermine confidence in Parliament. Further, by providing for a responsive system of investigation for parliamentary misconduct, the model provides a mechanism for securing short-term accountability for misbehaviour.

\section{B External Regulation}

${ }^{226}$ See Part IIIA above. 
As demonstrated in Parts V and VI above, external regulation by an independent standards authority is a relatively rare phenomena in Westminster countries and the Australian States and Territories. In the UK, IPSA's role is limited to overseeing and regulating expenses for members of Parliament, rather than overseeing members' conduct more broadly. However, it would be possible for Australia to adopt a similar model to that in the Republic of Ireland, where the Standards in Public Office Commission has wide-ranging investigative powers in relation to public figures, similar to the Integrity Commission in Tasmania. This model ensures that the investigation of misconduct is fully independent from Parliament. Further, an independent Commission is likely to have greater expertise in conducting investigations than a parliamentary committee. However, Parliament is still able to accept or reject the Commission's report and is responsible for imposing any necessary sanction for misconduct. As a result, this model still encounters many of the political challenges inherent in other models, despite the Commission's independence. Further, as noted in Part IV above, objections may be raised to this model on the grounds that it infringes the separation of powers and reduces the ability of Parliament to manage its own affairs.

At a broader level, concerns have been raised that establishing a quasi-judicial independent Commission may expose the misconduct process to the scrutiny of the courts, thereby reducing the stability and impartiality of the system ${ }^{227}$ and further undermining the separation of powers. ${ }^{228}$ The experience in the Republic of Ireland demonstrates that this is a real concern, though not necessarily confined to the workings of an independent Commission. In 2010 the Committee on Members' Interests of Seanad Éireann determined that a Senator had misrepresented his normal place of residence and, as a result, had received parliamentary allowances to which he was not entitled. ${ }^{229}$ The Senator was censured and suspended for 20 sitting days without pay. ${ }^{230}$ The Senator sought judicial review of the suspension in the High Court, which overturned the Committee's decision on the basis that the Committee had misdirected itself on the legal definition of a 'normal place of residence'. ${ }^{231}$ As the Committee had conducted its investigation in accordance with a statutory scheme that allowed for public complaints, it was possible for the courts to intervene. ${ }^{232}$ The member was awarded $€ 17,000$ in

\footnotetext{
227 Ibid 35.

${ }^{228}$ See, for example, Brien (n 187).

${ }^{229}$ Committee on Members' Interests of Seanad Éireann (n 175) 10.

${ }^{230}$ Ibid.

${ }^{231}$ See Callely v Moylan [2011] IEHC 2 (14 January 2011); 'Ivor Callely awarded $€ 17,000$ by High Court' (n 175).

${ }^{232}$ Callely v Moylan [2011] IEHC 2 (14 January 2011).
} 
damages for lost earnings. The possibility of judicial review has significant potential to undermine the certainty and stability of the system.

Rather than a general independent commission to investigate complaints, it might instead be desirable to establish an independent anti-corruption body in the federal context in a like form to the Independent Commission Against Corruption in New South Wales. However, analysis of this proposal is beyond the scope of this paper.

\section{Summary of Model}

To improve the accountability of members of Parliament for their conduct, and drawing on the foregoing analysis, we propose the following model of extended accountability for the Australian federal Parliament:

- Adoption of a uniform Code of Conduct in the standing orders of the Senate and House of Representatives that includes:

- Both aspirational principles and rules of conduct;

○ A scope that extends to conduct that 'significantly damages the public's trust and confidence in the integrity of the Parliament or its Members' or has the potential to do so; and

- Accompanying guidelines which provide examples of what conduct may cause or have the potential to cause such 'significant damage';

- Establishment of a Parliamentary Ethics Adviser for both houses of Parliament under parliamentary standing orders to provide advice on the implementation of the Code and ethical matters generally;

- Establishment of a Parliamentary Integrity Commissioner for both houses of Parliament under parliamentary standing orders to investigate breaches of the Code, provide advice to members on standards of conduct and review the operation of the Code;

- Establishment of a Joint Standing Committee on Parliamentary Standards to oversee the work of the Commissioner, review reports of the Commissioner and refer reports to the relevant house of Parliament to consider what sanctions, if any, are appropriate. If the Committee does not refer a report, it should automatically come on for debate in the relevant house of Parliament. The Joint Standing Committee should only be able to 
reject a report of the Parliamentary Integrity Commissioner on procedural grounds or if salient evidence has not been properly considered, in which case the report should be referred back to the Commissioner to be rectified;

- Provision for the Parliamentary Integrity Commissioner to undertake investigations of breaches of the Code following complaints from the public, referral from either House of Parliament or the Joint Standing Committee or of their own volition; and

- Amendment of the Parliamentary Privileges Act 1987 (Cth) s 7(5) to enable Parliament to be able to impose fines on its members for breaches of the Code.

\section{CONCLUSION}

Parliamentary scandals are not a new development in the Australian federal Parliament. However, with the growth of the 24-hour news cycle, political misconduct is now subject to increased and increasing scrutiny. Existing mechanisms fail to secure adequate short-term accountability for misconduct and do not sufficiently address non-criminal personal misconduct, including that which occurs prior to members entering Parliament and which has the potential to undermine public confidence in Parliament. As the Thomson and Slipper cases demonstrate, these accountability gaps have the potential to damage the reputation and integrity of Parliament and undermine public confidence in parliamentarians generally.

In this context, we propose a model of extended accountability to provide more robust mechanisms for the management of parliamentary misconduct and address existing gaps in accountability. Applying this model to the Thomson case, alleged misconduct would be investigated by a Parliamentary Integrity Commissioner to determine whether the conduct was consistent with the Code of Conduct and, in particular, whether the conduct had significantly damaged the public's trust and confidence in the integrity of the Parliament or its members. Based on the Commissioner's determination, it would be the responsibility of the Joint Standing Committee to refer the matter to Parliament and, ultimately, the responsibility of Parliament to impose any sanction. This would provide a mechanism for achieving short-term accountability for alleged misconduct and for addressing conduct prior to entering Parliament that has the potential to undermine public confidence in Parliament. 
In the context of the Slipper case, allegations of sexual harassment are best dealt with by existing court processes. As a result, a model of extended accountability is unlikely to provide any additional mechanism in relation to those accusations. However, allegations of misuse of parliamentary Cabcharge vouchers could have been referred to the Commissioner for investigation in the same manner as that proposed for the Thomson case.

The new parliamentary mechanism would operate independently of any judicial process. As a result, proceedings could be concluded more efficiently, helping to create a stronger sense of accountability for misconduct. Further, sanctions for misconduct (fines and/or suspension from Parliament) could be imposed by Parliament for a breach of its own integrity mechanisms and Code of Conduct, limiting any interference and overlap with the judicial process. It remains to be seen whether members of Parliament are willing to impose sanctions on their colleagues: however, if imposing a fine had the potential to more quickly settle or reduce the political discontent surrounding Thomson and Slipper's alleged misconduct, it is possible that it would receive support from the government in the hope that it would resolve the matters and avoid the prospect of suspension. Further, the existence of sanctions may help to deter future breaches of the Code.

In establishing mechanisms to manage misconduct it is essential that Parliament, as a political body, is not entrusted with excessive power to adjudicate and punish its members - this is a role better filled by the courts. However, the introduction of a Code of Conduct that may be enforced via fines and suspensions has the potential to create short and medium-term accountability structures for conduct that has the potential to significantly damage the integrity of Parliament. This model of extended accountability would still be subject to be political constraints that arise from the nature and operation of Parliament, but it could nevertheless assist in providing a more systematic and effective approach to dealing with parliamentary misconduct. As a result, this model provides a means of addressing existing accountability gaps for misconduct of parliamentarians in the Australian federal Parliament. 


\section{University Library}

\section{- M M N E R VA A gateway to Melbourne's research publications}

Minerva Access is the Institutional Repository of The University of Melbourne

Author/s:

Blackham, A;Williams, G

Title:

The accountability of members of Australia's federal parliament for misconduct

Date:

2013-09-01

Citation:

Blackham, A. \& Williams, G. (2013). The accountability of members of Australia's federal parliament for misconduct. Oxford University Commonwealth Law Journal, 13 (1), pp.115-156. https://doi.org/10.5235/14729342.13.1.115.

Persistent Link:

http://hdl.handle.net/11343/266529 